\title{
International Journal of Remote Sensing
}

\section{Mapping drought-induced changes in rice area in India}

\section{Murali Krishna Gumma, Andrew Nelson \& Takashi Yamano}

To cite this article: Murali Krishna Gumma, Andrew Nelson \& Takashi Yamano (2019) Mapping drought-induced changes in rice area in India, International Journal of Remote Sensing, 40:21, 8146-8173

To link to this article: https://doi.org/10.1080/01431161.2018.1547456

曲 Published online: 28 Nov 2018.

Submit your article to this journal $\pi$

Џll Article views: 120

View Crossmark data \lceil

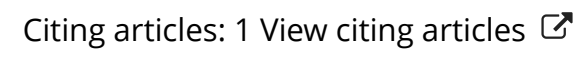




\title{
Mapping drought-induced changes in rice area in India
}

\author{
Murali Krishna Gumma (10) , Andrew Nelson (10) ${ }^{\mathrm{b}}$ and Takashi Yamano $\mathbb{( D}^{\mathrm{c}, \mathrm{d}}$ \\ aRemote sensing/GIS lab, Innovation Systems for the Drylands Program (ISD), International Crops Research \\ Institute for the Semi-Arid Tropics (ICRISAT), Patancheru, India; 'D Department of Natural Resources, Faculty \\ of Geo-Information and Earth Observation (ITC), University of Twente, Enschede, The Netherlands; 'Social \\ Science Division, International Rice Research Institute, Los Baños, Philippines; ${ }^{d}$ Economic Research and \\ Regional Cooperation Department, Asian Development Bank, Manila, Philippines
}

\begin{abstract}
Rice is a staple food crop of India and is grown on 44 Mha (2011-12), $58.6 \%$ of which are irrigated. An inevitable phenomenon which looms over all aspects of human life and affects rice production in India is drought. Assessing drought damage using geospatial datasets available in the public domain, such as the Normalized Difference Vegetation Index (NDVI) derived from the Moderate Resolution Imaging Spectroradiometer (MODIS), can provide specific and local ecoregion information for developing drought-resistant rice varieties. Based on multi-temporal NDVI data and field observations in 2009, we developed a methodology to identify and map drought-affected areas in India. A long-term (10-year) average of NDVI during the rainy (kharif) season (June-October) was compared with NDVI from a known drought year (2002-03) to identify changes in rice area. Rainfall data from the Tropical Rainfall Monitoring Mission (TRMM) was used to support the drought analysis. Spectral matching techniques were used to categorise the drought-affected rice areas into three classes severe, moderate, and mild based on the intensity of damage assessed through field sampling. Based on these ground survey samples, spectral signatures were generated. It was found that the rice area was about $16 \%$ less in the drought year (2002-03) than in a normal year (2000-01). A comparison of the MODIS-derived rice area affected by drought in $\mathbf{2 0 0 2}$ for each state and district against the difference in the kharif season harvested rice area between 2000 and 2002 (from official statistics) revealed a substantial difference in harvested area in 2002 that was largely attributable to drought. An $84.7 \%$ correlation was found between the MODIS-derived drought-affected area in 2002 and the reduction in harvested area from 2000-01 to 2002-03. Good spatial correlation was found between the drought-affected rice areas and reduction of rice harvested areas in different rice ecologies, indicating the usefulness of such geospatial datasets in assessing abiotic stress such as drought and its consequences.
\end{abstract}

\section{ARTICLE HISTORY}

Received 15 December 2017 Accepted 24 August 2018

CONTACT Murali Krishna Gumma m.gumma@cgiar.org; gummamk@gmail.com @ Remote sensing/GIS lab, Innovation Systems for the Drylands Program (ISD), International Crop Research Institute for the Semi-Arid Tropics (ICRISAT), Patancheru, Telangana 502324, India 


\section{Introduction}

Rice is grown on over 44 Mha in India, in almost every state. Meteorological drought can affect any rice-growing region of India, with farm households in rainfed areas at particular risk. Drought is the main cause of inter-annual changes in cultivated rice area in India that leads to a reduction in expected rice harvest, but there is little spatial information on which areas are affected, by how much and how often. Vegetation index time-series derived from hyper-temporal, moderate resolution, optical remote sensing imagery can be used to detect water stress in plant canopies across large areas. Here we present a method to detect and characterise drought-affected rice-growing areas under the assumption that there is a strong negative linear correlation between inter-annual changes in rice area and the extent of meteorological drought.

Agriculture accounts for 17.8\% (2011-2015) of the Gross Domestic Product (GDP) of the Indian economy (WorldBank 2016). Two-thirds of the arable land (96 Mha) is under rainfed farming and $44 \%$ of the total production comes from rainfed regions (Chandrasekar et al. 2010). The yield of rainfed crops is significantly influenced by weather, especially rainfall distribution (Kumar et al. 2011). Droughts occur frequently in India, resulting in water shortages and economic crises for rural people, eventually leading to food insecurity. Population growth and increased wealth in India between 1980 and 2000, led to increased demand for water and other natural resources which exacerbated the impact of droughts (Thenkabail, Gamage, and Smakhtin 2004). More recently, the 2009-10 drought affected more than 100 million people, with severe impacts felt in the states of Uttar Pradesh, Bihar, and Andhra Pradesh, as well as in Pakistan's Sind and Baluchistan provinces (DRMS 2010).

Based on the Köppen classification, India has several climates: monsoon with a short dry season in the south; tropical savannah in the central region; semi-arid in the west; monsoon with dry winters in the north, and; cold-humid in the north-east. The monsoon and tropical savannah climates are most dominant in the rice growing areas of the country and as such there are four seasons defined by the Indian Meteorological Division (IMD), which are: winter in January and February; pre-monsoon from March to May; south-west monsoon from June to September, and; post monsoon from October to December. Over $75 \%$ of the annual rainfall is received during the south-west monsoon. The average annual rainfall is $119 \mathrm{~cm}$, but with high spatial and temporal variations over the country. The Western Ghats, the Sub-Himalayan areas in the north-east and the Meghalaya Hills receive over $250 \mathrm{~cm}$ annually, whereas the northern parts of Kashmir and Western Rajasthan receive less than $40 \mathrm{~cm}$ (IMD 2015).

We define drought as a long period of extremely dry weather when there is insufficient rain to successfully grow crops or replenish water supplies (Thenkabail, Gamage, and Smakhtin 2004). Drought assessment is useful for identifying problem areas in which to disseminate new technologies and fund interventions to improve rural livelihoods. As places with different rice environments respond to drought differently, the spatial and temporal extent of drought needs to be assessed and characterised.

Satellite imagery can be used to monitor agricultural areas in order to identify changes in land use dynamics, assess drought stress, and estimate physical properties related to productivity, such as the leaf area index (Potter et al. 1993; Running et al. 1999; Chandrasekar et al. 2010; Gumma et al. 2011b, 2015b, 2015a; Behrenfeld et al. 2001). The Normalized Difference Vegetation Index (NDVI), based on the visible 
and near-infrared light that is reflected by vegetation, is a good indicator of vegetation condition and particularly drought stress. Healthy vegetation absorbs most of the red radiation (for photosynthesis and creation of chlorophyll) and reflects most of the near-infrared radiation, whereas water stressed vegetation reflects slightly more red radiation but absorbs much more near-infrared radiation (Kumar et al. 2002; Murthy et al. 2009; Zhang and Guo 2008; Daughtry et al. 1992). As a result, NDVI has been commonly used to monitor major crops (Jensen 1996; De Bie et al. 2011), often using temporal NDVI information to assess vegetation condition (Murthy et al. 2009).

Many studies on agricultural drought have been carried out at scales ranging from the micro level to global level (Eriyagama, Smakhtin, and Gamage 2009; Peel, Pegram, and McMahon 2004; Murthy et al. 2009). Several studies have used the National Oceanic \& Atmospheric Administration (NOAA), Advanced Very High Resolution Radiometer (AVHRR) and MODIS data to monitor drought and estimate biomass (Goward, Tucker, and Dye 1985; Teng 1990; Benedetti and Rossini 1993; Murthy et al. 2009; Pinjarla et al. 2017; Bhuiyan, Singh, and Kogan 2006; Anderson et al. 2010; Justice et al. 1985; Justice and Hiernaux 1986). Goward, Tucker, and Dye (1985) analysed annual and inter-annual variability of vegetation using multi-temporal AVHRR data, and demonstrated the application of AVHRR based vegetation monitoring at a global scale. Justice and Hiernaux (1986) monitored grassland conditions from local to regional scales in the Sahelian zone of Niger and reiterated the importance of analysing vegetation condition using maximum value composite (MVC) data. MVC takes the highest or best value pixel as a representation of a consecutive time series of pixels, to identify major changes in biomass during the growing season while removing shorter duration variations and reducing the effect of cloud contamination and other causes of data gaps. Teng (1990) monitored the effects of the 1988 drought on crops in the US Corn Belt by using multi-temporal NDVI data from NOAA-AVHRR to provide an objective assessment of the drought's extent and severity. Bhuiyan, Singh, and Kogan (2006) monitored drought dynamics in the Aravalli region of India using NOAA AVHRR data and derived different vegetation drought indices, such as vegetation condition index $(\mathrm{VCl})$, temperature condition index (TCl) and vegetation health index (VHI) along with NDVI. Pinjarla et al. (2017) assessed long-term agriculture drought using time series MODIS NDVI, meteorological and irrigation datasets. Anderson et al. (2010) assessed the impact of drought during 2005 in the Amazon forest using MODIS enhanced vegetation index (EVI) and normalized difference water index (NDWI). Different vegetation indices expressed varied degree of response to drought for grass land vegetation. Extended vegetation index (EVI) and NDVI lagged behind Land surface water index (LSWI) in the sensitivity analysis of vegetation condition (Bajgain et al. 2015; Chandrasekar et al. 2010). Changes in irrigated area resulting from water shortage in command areas and large river basins have been mapped using MODIS eight-day time series data (Biggs, Gangadhara Rao, and Bharati 2010; Gumma et al. 2011c; Gaur et al. 2008). Based on the above studies, agricultural drought due to insufficient soil moisture during the crop growing season leads to vegetation water stress that can be observed by spatial and temporal deviations between NDVI in a drought and non-drought year between a drought year and average conditions (Chandrasekar et al. 2010).

Several studies have used Spectral Matching Techniques (SMTs) with multi-temporal, moderate resolution optical remote sensing imagery for mapping and monitoring vegetation. For example, Gumma et al. (2014 and 2016) used SMTs to map seasonal 
rice areas and rice ecosystems in South Asia using MODIS time series data and Gumma et al. (2016) mapped rice-fallows in South Asia using SMTs. Thenkabail et al. (2007) used SMTs to map irrigated areas for different time periods using AVHRR data for the year 1982 and 2000. The success of these studies in monitoring changes in rice area and changes in water management in Asia suggest that SMTs would be an appropriate technique for drought detection in rice-growing areas of India.

The objective of this study was to categorise drought in rice-growing areas of India by means of MODIS time series data. When using the NDVI for this purpose, many assumptions have to be made, but their validity can be assessed by collecting and analysing additional information from the field. We used spectral matching techniques to assign drought to one of three categories on the basis of field information. India was chosen as the study area because it is one of the largest rice-growing countries, and droughts occur periodically in several parts of the country. We focused on the 2002-03 drought, one of the worst recorded after the droughts of 1918 and 1972 (Bhat 2006; Niranjan Kumar et al. 2013; Zampieri et al. 2018).

\section{Study region}

India lies in South Asia, extending between $6^{\circ} 34^{\prime} 1.1^{\prime \prime} \mathrm{N}$ and $36^{\circ} 54^{\prime} 35^{\prime \prime} \mathrm{N}$ and $68^{\circ} 11^{\prime} 10.5^{\prime \prime} \mathrm{E}$ and $97^{\circ} 47^{\prime} 23.6^{\prime \prime} \mathrm{E}$. Spanning about $345 \mathrm{Mha}$, the country includes $208 \mathrm{Mha}$ of agricultural land and 17 major river basins. It is the second largest populated country in the world. Around $72.2 \%$ of the total population live in rural areas (Census 2012) and most of them depend on agriculture for their livelihood. Agricultural and rural development are seen as key interventions to eradicate poverty and create conditions for sustainable and equitable economic growth.

The study area includes nine major river basins: Indus, Ganges, Brahmaputra, Narmada, Tapti, Godavari, Krishna, Kaveri, and Mahanadi (Figure 1), which according to the Central Board of Irrigation and Power (CBIP) cover a total irrigated area of 133 Mha (CBIP 2007). According to national statistics, 44 Mha of rice were cultivated in 2000-01, which was considered to be a normal year, compared with 39 Mha during 2002-03, which was classified as a drought year (Niranjan Kumar et al. 2013). India has the largest rice area in the world, it can be grown in three seasons in India; kharif (June-October), rabi (November-February) and summer (February-May) (Manjunath and Panigrahy 2009; Gumma et al. 2016).

\section{Data}

\subsection{Satellite imagery}

The MODIS Terra Surface Reflectance 8-day composite product (MOD09A1) uses the best observations during an 8-day period (Vermote, El Saleous, and Justice 2002). The spatial resolution of the data is approximately $500 \mathrm{~m}$. Although the data have already undergone atmospheric correction (Vermote and Vermeulen 1999) and cloud screening, each MODIS 8-day composite was further processed and cloud contamination was removed as explained in Gumma et al. (2014). We downloaded eight-day composites (from www.modis.land.gsfc.nasa. gov) that overlapped with the rainy season (or kharif season) between June and December for each year from 2000 to 2009. In India, the kharif season runs from June to October, however 


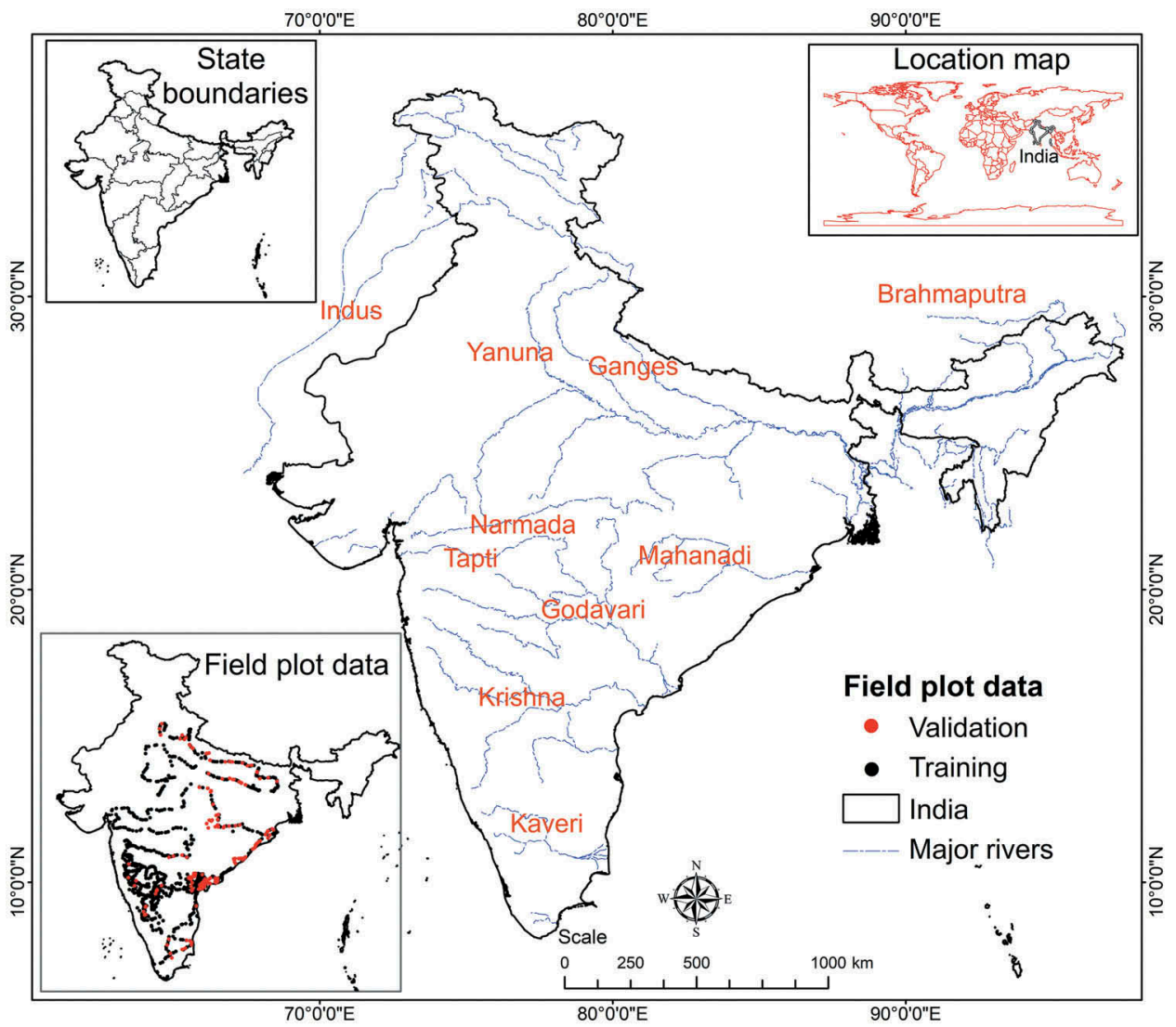

Figure 1. Major rivers and river basins in India.

Note: River networks and basin catchments extracted from SRTM 90 m DEM, http://srtm.csi.cgiar.org/SELECTION/ inputCoord.asp. Also shown are the 584 locations from which field plot data were collected for this study.

Table 1. Characteristics of the satellite sensor data used in the study.

\begin{tabular}{lcccl}
\hline & \multicolumn{5}{c}{ MOD09A1 Product ${ }^{\mathrm{a}}$} \\
\hline Bands $^{\mathrm{b}}$ & Band width $\left(\mathrm{nm}^{3}\right)$ & Band centre $\left(\mathrm{nm}^{3}\right)$ & Name & \multicolumn{1}{c}{ Application ${ }^{4}$} \\
\hline 3 & $459-479$ & 470 & Blue & Soil/vegetation differences \\
4 & $545-565$ & 555 & $\begin{array}{c}\text { Green } \\
\text { Green vegetation }\end{array}$ \\
1 & $620-670$ & 648 & Red & $\begin{array}{l}\text { Absolute land cover transformation, Vegetation } \\
\text { chlorophyll }\end{array}$ \\
2 & & & & Cloud cover, vegetation, land cover transformation \\
5 & $841-876$ & 858 & NIR1 & Cloud \\
6 & $1230-1250$ & 1240 & NIR2 & Leaf/canopy differences \\
7 & $1628-1652$ & 1640 & SWIR1 & Snow/cloud differences \\
7 & $2105-2155$ & 2130 & SWIR2 & Cloud properties, land properties \\
\hline
\end{tabular}

Of the 36 MODIS bands, the 7 bands reported here are specially processed for land studies.

${ }^{\mathrm{b}}$ MODIS bands are re-arranged to follow the electromagnetic spectrum (e.g. blue band 3 followed by green band 4 ).

${ }^{3}$ Nanometers (nm). ${ }^{4}$ http://modis-land.gsfc.nasa.gov.

some areas may receive delayed rainfall, which leads to delayed sowing and hence our choice of December as the end point of the time series. Our drought assessment used four of the MODIS bands: $1,2,3$, and 6 (Table 1). 


\subsection{Field plot data}

Field plot data were collected from 584 farmer surveys linked to field plots during two different ground survey missions to map land use and land cover. Major cropland areas were chosen based on the knowledge of the district agricultural extension officers in order to ensure that adequate samples of rice as well as of other crops are collected. The farmers provided information on irrigation source, drought condition, crop calendar, cropping intensity (the number of times a crop is grown in a plot of land), and canopy cover (\%) for these field plots. The interview included a question on three levels of drought intensity: mild, moderate, and severe. Severe drought meant the total area had either not been planted by the farmers or had been totally damaged after planting. Moderate drought meant that either the farmers had planted only part of the area or that $50-60 \%$ of the planted area had been damaged due to water shortage. Mild drought meant that either part of the area had been sown by the farmer or that $0-10 \%$ of the area had been damaged due to water shortage.

The first set of field plots (341) was collected during 11-26 October 2003 to map irrigated areas. Out of 341 plots, 143 that had detailed information were used for class identification and labelling. The remaining 198 points were used for accuracy assessment (Figure 1). The second set (243 field plots) was collected during August and September 2011. Interviews with farmers and district agricultural officers were conducted at each field plot location to determine drought intensity, crop types, and conditions during the 2009 kharif season. Out of 243 field plots, 205 points that had detailed information were used for class identification. Of these, 192 points were used for ideal spectra generation.

\subsection{TRMM rainfall data}

Monthly rainfall data for the 13-year period between 1998 and 2010 were downloaded from the Tropical Rainfall Measuring Mission (TRMM) (TRMM 2016) website at a spatial resolution of $0.25^{\circ} \times 0.25^{\circ}$ (approximately $27 \mathrm{~km} \times 27 \mathrm{~km}$ ) (Kummerow et al. 1998). Average monthly rainfall estimates for each month in the kharif season were extracted for the selected 13 years, including for the 2002 drought year. In the absence of any official data on drought-affected areas, differences in monthly TRMM data between a drought year and average conditions were used as an accumulation of evidence of the spatial and temporal patterns of drought occurrence.

\subsection{Rice-growing areas, national rice statistics, and previous drought studies}

The maximum possible extent of rice in 2002-03 was derived from a previously published MODIS-derived rice extent map for 2000-01. The map includes 12 rice classes with a classification accuracy of $80 \%$ and a $97 \%$ agreement with rice areas from district statistics. The 2000-01 map is the most detailed publicly available map of rice extent in India (Figure 2). Our hypothesis was that there would be a slight change in the potential area that could be planted to rice between 2000-01 and 2002-03 and that most of the changes would be attributable to a deficit in available water, due to drought conditions (Bhat 2006). Data on rice area per state for 2000-01 and 2002-03 was obtained from the Directorate of Economics and Statistics, 


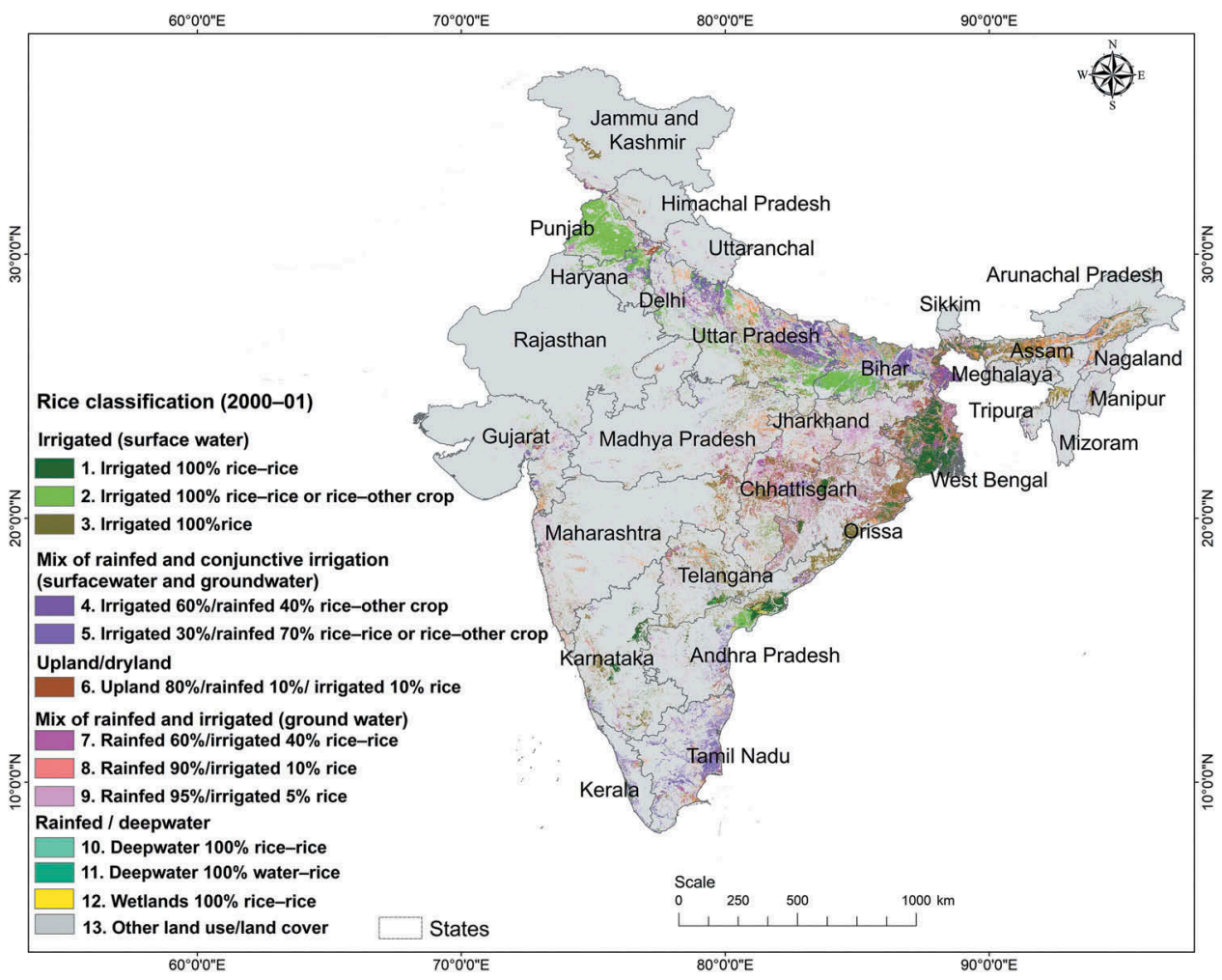

Figure 2. Rice extent map for a normal year: the final 12 rice classes for a good year 2000-2001, from (Gumma et al. 2011a).

Government of India (http://dacnet.nic.in/rice/) (INDIASTAT 2015) to compare with the MODIS-derived rice-growing area in the respective years. Finally, we compared the drought areas from our analysis with those of previous studies (Biggs, Gangadhara Rao, and Bharati 2010).

\section{Methods}

Figure 3 provides an overview of the methods used. The first dataset prepared for a time series analysis was the Mega File Data Cube (MFDC), which is a stack of MODIS 8-day reflectance composites for the entire study period 2000-09. A cloudremoval algorithm was applied using a threshold to band 3 where all band values for that pixel were set to null if band 3 was greater or equal to $18 \%$ (Gumma et al. 2011a). Using the same stack, another MFDC of NDVI layers was derived from the red and near-infrared (NIR) bands. Monthly MVC of NDVI was then derived to provide smooth representations of changes in vegetation condition during the kharif season, while reducing noise due to shorter duration fluctuations and by filling gaps due to cloud contamination (Gumma et al. 2014). The rice extent map for the 2000-01 kharif season, was used as a mask to estimate the inter-annual change in drought-affected rice area (Gumma et al. 2011a). A drought indicator was derived by comparing the seasonal MODIS NDVI from the well-documented drought during the 2002-03 kharif 


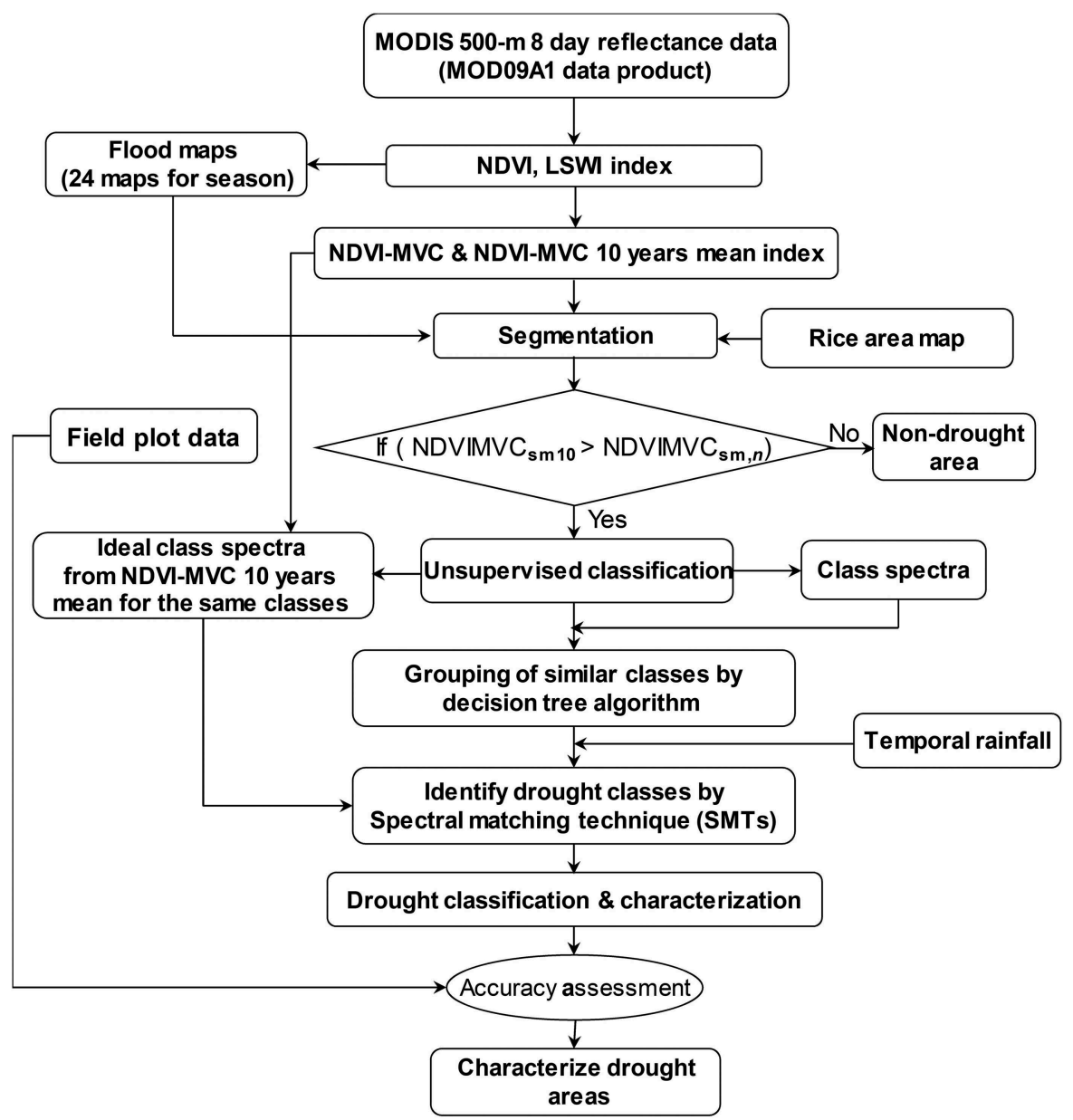

Figure 3. An overview of the methodology used for mapping drought areas using MODIS data.

season against the average seasonal MODIS NDVI over 10 years (2000-09) for the same season. An unsupervised classification of rice areas in which in 2002-03 the NDVI was lower than the average NDVI resulted in a large number of drought classes that were then grouped and labelled as having no, mild, moderate or severe drought, based on the similarity of their temporal signatures. TRMM monthly rainfall data for the same period and information from previous studies were used as independent sources of corroborative evidence for the validity of our resulting drought map.

\subsection{Vegetation indices, maximum value composite (MVC)}

The maximum rice crop extent was derived from the 2000-01 rice map. The NDVI and LSWI (Xiao et al. 2006) were derived for each eight-day composite in the 2000-09 time series of images, using Equations (1) and (2). 


$$
\begin{array}{r}
\mathrm{NDVI}=\frac{\rho_{\mathrm{NIR}}-\rho_{\mathrm{Red}}}{\rho_{\mathrm{NIR}}+\rho_{\mathrm{Red}}} \\
\mathrm{LSWI}=\frac{\rho_{\mathrm{NIR}}-\rho_{\mathrm{SWIR} 1}}{\rho_{\mathrm{NIR}}+\rho_{\mathrm{SWIR} 1}}
\end{array}
$$

The rationale for using NDVI to detect drought is that we would expect to see a lower NDVI signature (i.e. the temporal profile of NDVI during the growing season) for a given pixel in a drought year than in a normal year. However, flooding or crop submergence, which is another common problem in India, can also result in a lower than expected NDVI signal. Moreover, during the early parts of the season, the NDVI response is low, largely because reflectance is from the soil background rather than from the sparse crop cover. We used the LSWI, which is sensitive to soil water content and to leaf water content, to address this. The LSWI is related to liquid water in vegetation canopies, which interact with solar radiation (Gao 1996). We compared this water-sensitive index with NDVI and classified a pixel as being submerged if the LSWI exceeded the NDVI value for two or more consecutive 8-day periods (Xiao et al. 2006). This ensured that potentially submerged areas, that may be confused with drought in a purely NDVI based analysis, were excluded from the drought classification.

\subsection{Identification and mapping of drought areas}

Monthly MVCs of NDVI were generated for each of the seven months of the kharif season for each year in the time series using Equation (3):

$$
(\mathrm{NDVIMVC})_{i}=\max \left[(\mathrm{NDVI})_{i 1},(\mathrm{NDVI})_{i 2},(\mathrm{NDVI})_{i 3},(\mathrm{NDVI})_{i 4}\right]
$$

where (MVC) $)_{i}$ is the MVC of the ith month (for example, if ' $i$ ' is January-December), $i 1, i 2$, i3, i4 are the data on every 8-day in a given month. April and October use only three 8-day composites instead of four. A mean of the (NDVIMVC), for each month was created from the 10 years of NDVI data (NDVIMVC) ${ }_{m, n}$ so that the monthly NDVI during the kharif season of the drought year, 2002-03, could be compared to average monthly conditions. The same process was performed to create a seasonal MVC across the kharif season. Rice areas with drought were identified using a simple threshold on these seasonal MVCs using 'Equation (4)':

$$
(\mathrm{NDVIMVC})_{s \mathrm{~m} 10}>(\mathrm{NDVIMVC})_{\mathrm{sm}, \mathrm{n}}
$$

where $(\mathrm{NDVIMVC})_{\mathrm{sm} 10}$ is the seasonal mean NDVI MVC over 10 years and (NDVIMVC) $)_{s m n}$ is the seasonal NDVI MVC of the $n$th year, where $n$ is year 2002.

This threshold was derived from experience in using NDVI time series for rice crop mapping in South Asia (Gumma et al. 2011b, 2015b, 2011a, 2016) and from a comparison of the drought conditions in the field and corresponding NDVI signatures for those locations. They represent the difference between NDVI in the observed kharif season and the average NDVI in the kharif season. As such, they are specific to the rice crop in South Asia and may not apply to other crops or geographies. However, some studies on wheat and multiple vegetation types have shown good correlation between 
NDVI and biomass as well as photosynthetically active radiation (Wang et al. 2005; Hansen and Schjoerring 2003). This threshold on the seasonal MVC NDVI data was used purely to separate drought from non-drought areas. The method to further distinguish the severity of drought using the monthly MVC NDVI data is explained below.

\subsection{Unsupervised classification for class spectra generation and drought classification}

Unsupervised classification using the Iterative Self-Organized class (ISOCLASS) cluster algorithm (using Iterative Self-Organizing Data Analysis Technique Algorithm (ISODATA) in Earth Resource Development Assessment System (ERDAS) Imagine 2010) followed by progressive generalisation (Cihlar et al. 1998; Nguyen et al. 2012) was applied to the NDVI MVC of the kharif season 2002-03. The classification was set at a maximum of 100 iterations and a convergence threshold of 0.99 . Initially, 15 classes were extracted from the unsupervised classification. Class temporal profiles were generated using ISOCLASS $k$-means classification of the MFDC. The signature files of the 15 classes were plotted and similar classes were grouped. Classes were further grouped on the basis of decision tree algorithms and spectral matching techniques (SMTs) to match and label the classes with the ideal spectral signatures for drought as explained below (Gumma et al. 2011a, 2011c; Thenkabail et al. 2009).

\subsection{Drought classification and characterisation}

Drought areas were classified into four categories (severe, moderate, mild, and no drought), based on the intensity of drought that occurred in the field plots as per farmer's response, as explained in Section 2.3. This information was collected from 205 fields out of the 584 field plots.

NDVI signatures were extracted from the NDVI stack for the year 2009 for field plots surveyed in 2011. From the 205 field plots considered, we selected 192 on the basis of field plot information and spectral similarity to the four categories. NDVI signatures from the four categories based on farmers' responses were used to identify ideal spectral signatures for severe, moderate, mild, and no drought and no drought rice areas (Figure 4).

Drought characterisation normally involves the use of an index to describe drought severity or its absence (Table 2). This study used drought categorisation based on the difference between threshold values of maximum NDVI during the kharif season for the selected 10 years and that of the kharif season of the drought year. The threshold values obtained during 2009 were used for each year from 2001 to 2009 and categorised for drought. The thresholds of NDVI signature help determine the onset of a cropping season, its duration, severity, and end. Severe drought area signatures show continuously low NDVI $(<0.201)$ compared with the 10-year mean monthly NDVI-MVC values, which may represent a fallow period due to lack of water. Moderate drought area signatures show lower NDVI values (0.151-0.200) than the 10-year mean NDVI-MVC value; this indicates crop damage due to drought. Figure 5 shows the different drought categories between drought years and a normal year. 

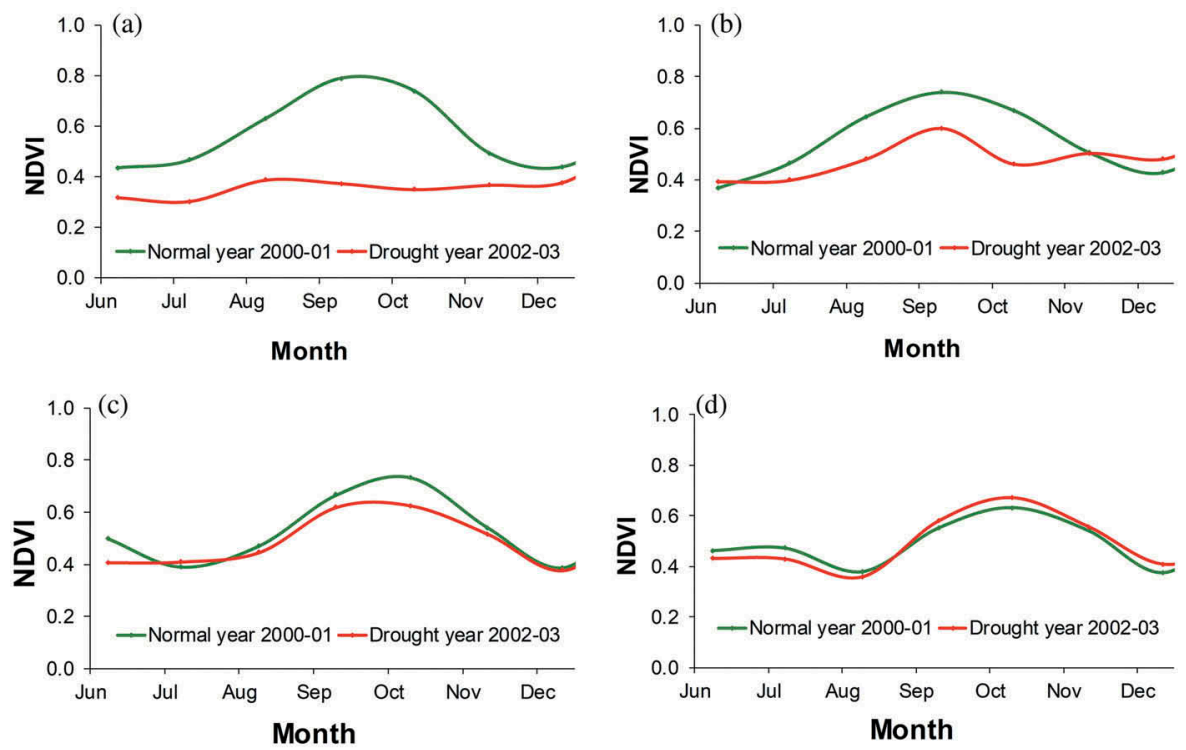

Figure 4. Ideal spectra illustration (with a number of samples in brackets) for severe drought, moderate drought, and mild drought.

Table 2. Drought characterisation based on NDVI thresholds.

\begin{tabular}{|c|c|c|}
\hline Drought class & Drought characterisation $^{\text {a }}$ & No. of field plots in sample \\
\hline Mild & $0.100-0.150$ & 20 \\
\hline Moderate & $0.151-0.200$ & 23 \\
\hline Severe & $>0.201$ & 11 \\
\hline No drought & $<0.100$ & 138 \\
\hline
\end{tabular}

\subsection{Drought classification accuracy assessment and comparison against secondary data}

An accuracy assessment of the drought classification was performed using an error matrix and kappa coefficient (K) (Congalton 1991). The assessment was based on 198 independent field plot points as explained in Section 2.3 that were not used in the drought classification and labelling process.

We compared the spatial distribution of drought-affected rice area to the difference in TRMM rainfall between 2002-03 and the 1998-2010 average. We also compared the mapped drought extent in 2002-03 to the reported change in harvested rice area between 2000-01 and 2002-03 on the basis that if drought was the major cause of rice area reduction across India in 2002-03 then we would observe a strong relationship between the drought mapped area and the change in reported harvested rice area. Finally, we compared our drought area estimates to those reported in previous studies, though they covered limited geographic extents. 

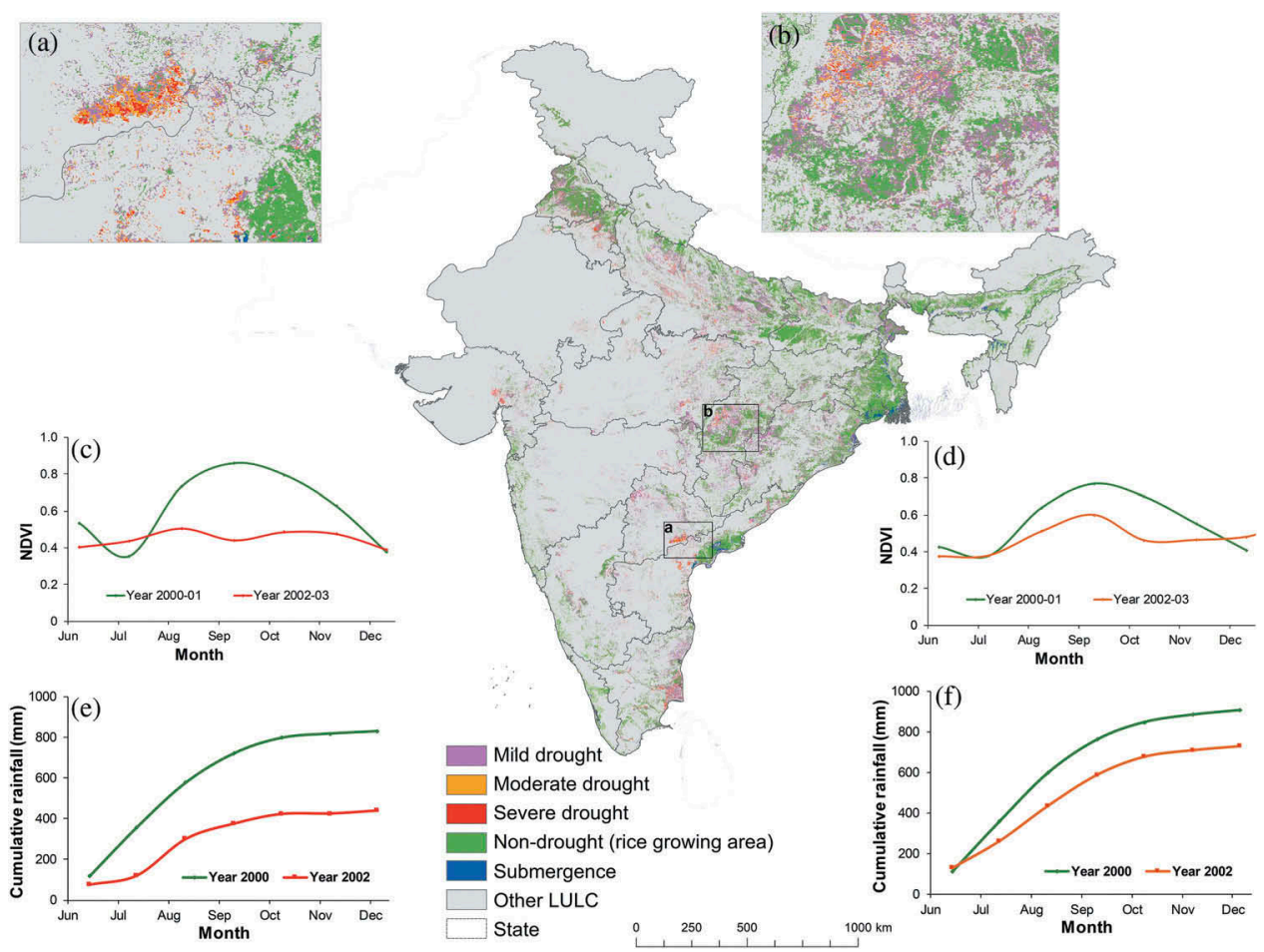

Figure 5. Spatial extent of drought categories derived from MOD09A1 and signature: (a) Nagarjunasagar command area; (b) Mahanadi command area; (c) NDVI-MVC time series data for severe drought in Nagarjunasagar command area; (d) NDVI-MVC time series data for moderate drought in Mahanadi command area; (e) TRMM rainfall for severe drought in Nagarjunasagar command area; and (f) TRMM rainfall for moderate drought in Mahanadi command area.

\subsection{Sub-pixel area (SPA) calculations}

We used MODIS $500 \mathrm{~m}$ spatial resolution data to mapping drought areas. Each pixel covers approximately 25 ha, which is larger than many agricultural fields in India. As a result, the full pixel area (FPA) is not a correct representation of the droughtaffected rice area observed in the field and so a sub-pixel area (King et al. 2003) estimate of the drought-affected rice area was computed as follows. The field plot data observations included a visual estimate of the proportion of different land use (rice cropped area including other land use and land cover areas) within a $500 \mathrm{~m} \times 500 \mathrm{~m}$ area. The SPA fraction was applied to each drought class to estimate the actual drought area for that drought class using Equation (5). We used 192 detailed field plot data observations for SPA estimation (the same points that were used for ideal spectra generation).

$$
(\mathrm{SPA})_{n}=(\mathrm{FPA})_{n} \times(\mathrm{RAF})_{n}
$$

where SPA = sub-pixel area; FPA = full-pixel area; RAF = rice area fraction 


\section{Results and discussion}

\subsection{Drought in rice-growing areas}

Figure 5 shows the resulting drought map and the three categories of drought (mild, moderate, and severe) as well as non-drought and submerged areas. Surface water irrigated rice areas in major command areas such as the Nagarjunasagar command area (Figure 5(a)), Mahanadi basins (Figure 5(b)) are also illustrated. The areas under each drought category, including its sub-pixel and full pixel area, are provided in Table 3. About $14 \%$ of rice-growing areas were affected during 2002-03 compared to 2000-01 rice area (Table 3).

\subsection{NDVI change analysis}

Figure 5(c,d) show NDVI variations over India for 2000-01 and 2002-03. Some of the major irrigated command areas (Nagarjunasagar, Tungabhadra, Krishna/Godavari delta, and part of the Indo-Gangetic plain) observed peak NDVI (0.9) during September in the kharif season during 2000-01. However, the NDVI value never exceeded 0.85 in any month during the 2002-03 kharif season. In a good year, the mean NDVI was 0.59 during the kharif season, but in the drought year (2002) it was as low as 0.28 in severe drought areas. In moderate drought areas, NDVI was found to be 0.41 in a drought year compared to 0.50 in a good year.

A state-level analysis of NDVI during a normal year revealed that it ranged between 0.60 and 0.70 under rainfed conditions and between 0.7 and 0.8 under irrigated conditions. The state of Andhra Pradesh, where most of the rice is grown on irrigated land and deltas, had a high NDVI value of 0.80 , whereas the NDVI values for Odisha and Karnataka states were lower: 0.75 and 0.8 , respectively, during a normal year. During a drought year, these important rice-growing states showed a drop in NDVI values, indicating water deficit. Andhra Pradesh and Odisha showed a 0.40 NDVI value during a severe drought and 0.50 during a moderate drought. In states, such as Bihar, Jharkhand, and Karnataka, where large areas are rainfed, the NDVI values ranged between 0.30 and 0.40 .

\subsection{Comparison against TRMM $3 B 42$ rainfall}

In Figure 5(e,f), cumulative monthly rainfall extracted from TRMM grids for areas that experienced severe and moderate drought during the kharif season of 2002 is plotted together with the monthly rainfall for 2000 . A total rainfall of $840 \mathrm{~mm}$ was recorded during the drought year (2002) whereas $1207 \mathrm{~mm}$ was the normal rainfall in those areas. Figure 6 illustrates the TRMM rainfall for the kharif season during the 13-year period (1998-2010) and for 2002 showing a large difference between the two. From the 13-year data series, the average monthly rainfall during the kharif season (June-December) was derived and then

Table 3. Drought areas across India for 2002-03 as derived from MODIS data, using full and subpixel areas, classified as mild, moderate, or severe.

\begin{tabular}{lccccc}
\hline Drought class & Sample size & Full pixel area (ha) & Drought fraction (\%) & Sub pixel area (ha) & Percentage (\%) \\
\hline Mild & 20 & 14506875 & 25.6 & 3713760 & $10 \%$ \\
Moderate & 23 & 2301376 & 52.3 & 1203620 & $3 \%$ \\
Severe & 11 & 362919 & 100 & 362919 & $1 \%$ \\
\hline
\end{tabular}




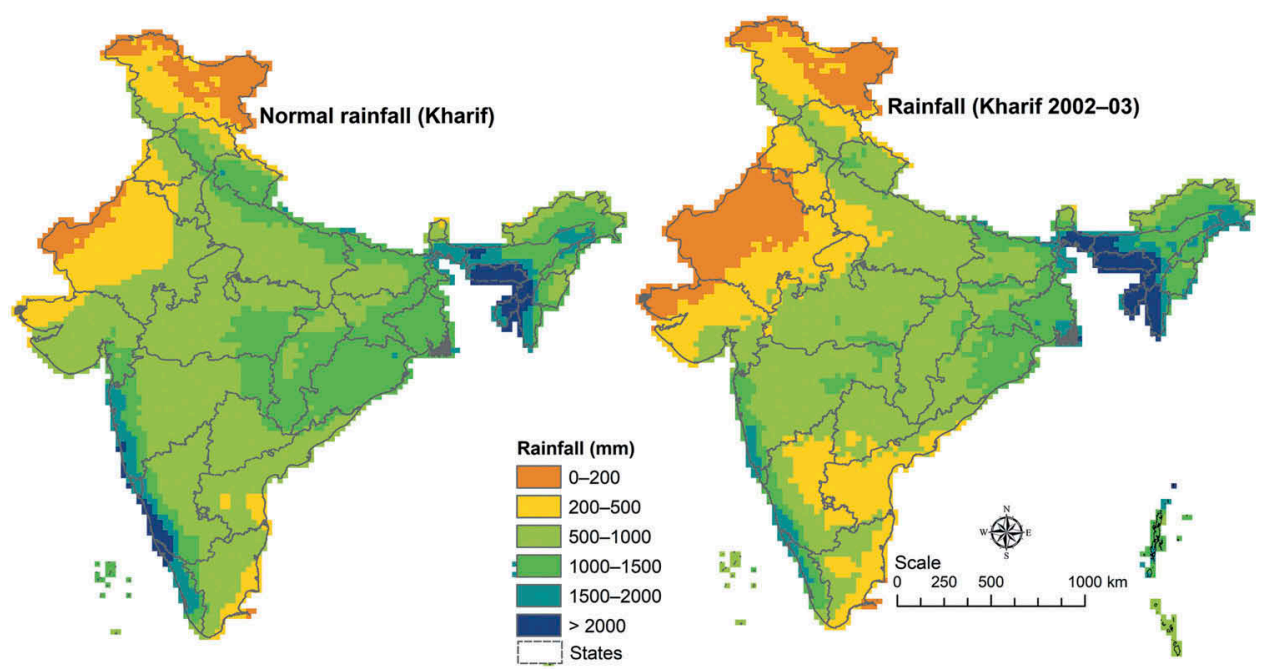

Figure 6. Comparison of mean seasonal rainfall (mean of 13 years: 1998-2010) with a drought year (2002), using TRMM $0.25^{\circ}$ rainfall data.

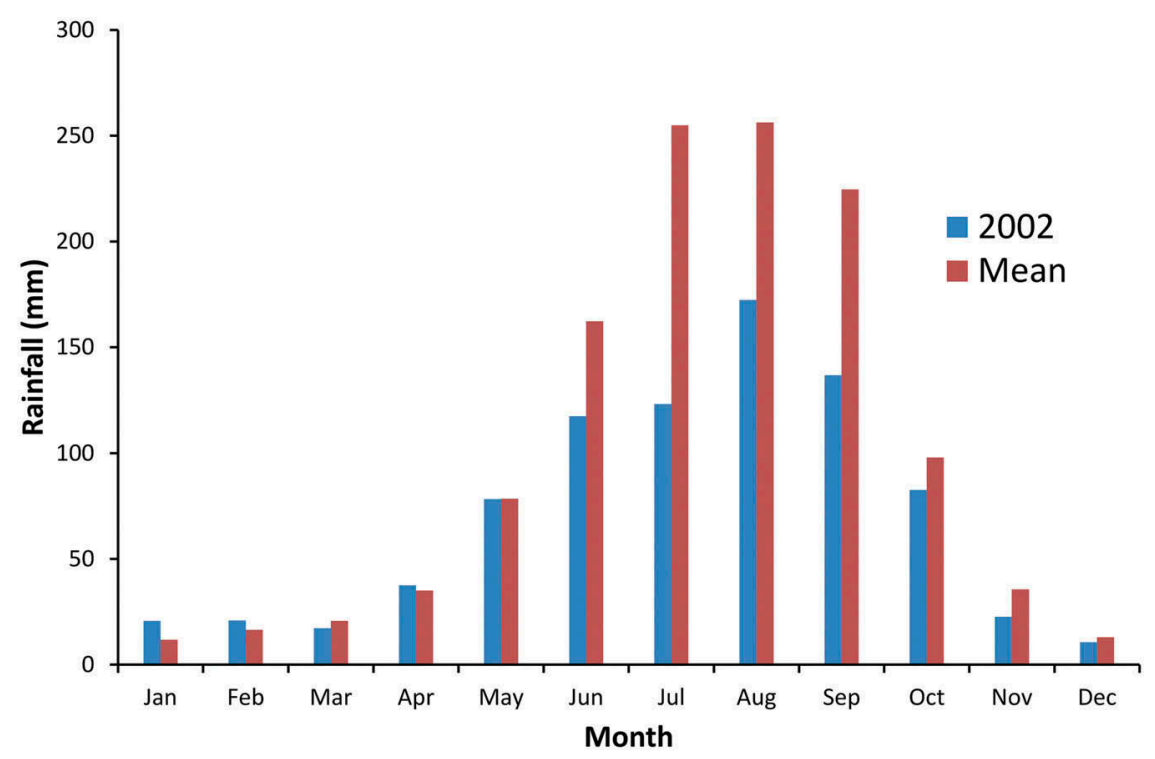

Figure 7. Monthly rainfall during 2002 (blue bars) compared with the mean monthly rainfall for 13 years (1998-2010). Low rainfall during the kharif season (June-December) clearly indicates a deficit during 2002.

compared with the corresponding monthly means during 2002 in order to reveal rainfall anomalies that could be associated with drought conditions (Figure 7). During the severe drought, no rainfall was recorded during the peak of the kharif season (July). Though not much variation was observed in moderate drought areas, during the peak season (in July) $196 \mathrm{~mm}$ was recorded in the drought year, compared with $281 \mathrm{~mm}$ for the 13-year July mean. Yet in July 2002, some areas were affected by flood. A comparison of the rainfall in 
2002 and the normal rainfall during the peak season in July revealed that $123 \mathrm{~mm}$ was recorded in 2002 compared with $255 \mathrm{~mm}$ in the 13-year mean of July (Figure 7).

\subsection{Spatial dynamics of drought area in relation to rainfall pattern}

The rainfall distribution and NDVI information from remotely sensed sources provide a synoptic overview of the difference between drought and non-drought years. Here we place the information into context with a description and discussion on rice-based cropping systems in India and their water resources.

The above analysis of rainfall indicates a deficit during the drought year which can be categorised into 3 classes: $<50 \%, 51-75 \%$, and $>75 \%$ rainfall (Figure 8 ). A cross-tabulation between drought classes and rainfall deficit classes reveals useful correlations in the rice crop ecologies of India. The rice crop in Bihar and southern and eastern parts of Uttar Pradesh experienced mild drought even with $<50 \%$ rainfall, because the crop is mostly irrigated. Similarly, in states such as Punjab and Haryana and along the coastal plains and deltas which are highly irrigated, mild drought was experienced when rainfall was less than $51-75 \%$ of the mean. In most of Tamil Nadu, where the rice crop is mostly grown under rainfed conditions and is supplemented with surface and groundwater, mild to severe drought was observed when rainfall was $51-75 \%$ less than the mean. But in Kerala, except for a couple of districts which are moderately and severely affected by drought, mild drought occurred in most of the rice-growing areas when rainfall was $<50 \%$ of the mean,

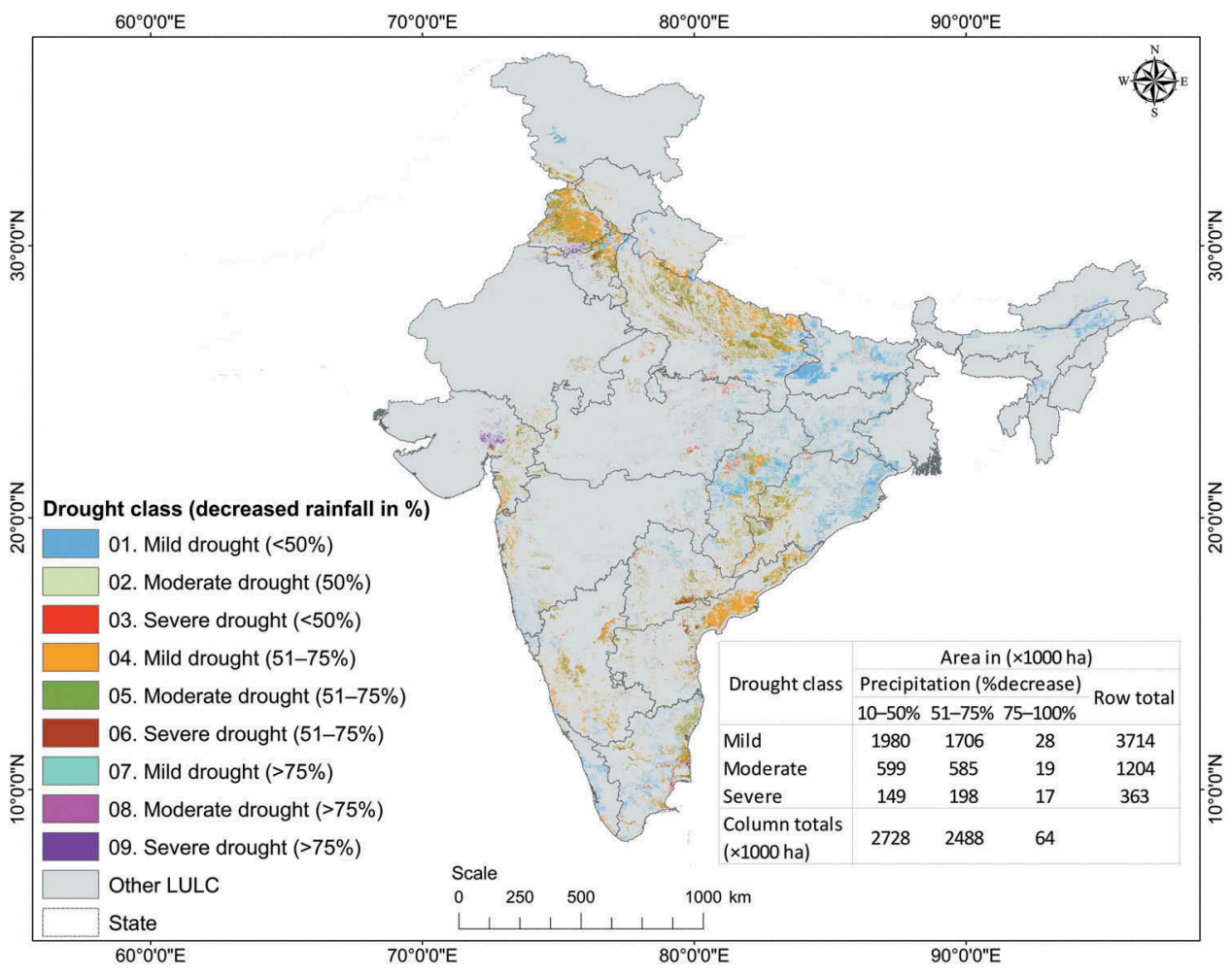

Figure 8. Spatial comparison of drought area in relation to rainfall pattern. 
because it is a high rainfall state. In Karnataka, where rice is mostly irrigated, $51-75 \%$ less rainfall than the mean resulted in mild to moderate drought in areas supported by irrigation projects but severe drought elsewhere. The state of Maharashtra exhibited a uniform pattern of drought correlated with the amount of rainfall and its impact on the rice crop. The western districts grow a mix of rainfed/irrigated rice, interspersed with patches of $100 \%$ irrigated rice mixed with wetland rice. Due to the availability of groundwater, these areas incurred mild to moderate drought even when rainfall was $51-75 \%$ less than the mean. The areas with $100 \%$ irrigated rice mixed with wetland rice experienced mild drought because of the low deficit ( $<50 \%$ rainfall). Thanks to surface water irrigation, even with a rainfall deficit of $<50 \%$ the eastern districts of Maharashtra, in which all rice is irrigated, were not affected by mild to moderate drought. In Madhya Pradesh, different rice ecologies are present in the eastern districts. Most of the rice irrigated solely by surface water is surrounded by wetland rice. Elsewhere in the eastern districts, the rice is rainfed and is mixed with irrigated rice receiving conjunctive irrigation from surface water or groundwater. All these rice-growing areas experienced mild and moderate drought, since the rainfall deficit was less $(<50 \%)$. Most of Chhattisgarh is located in the Mahanadi basin and Godavari basin in the south (Figure 2). The central non-forested land is arable where rice is exclusively and extensively grown with $100 \%$ irrigation, interspersed with extensive patches of rainfed and irrigated (with groundwater) rice. In the Godavari basin, rice is irrigated with surface water and the second crop of rice is planted in the next season (November). Thanks to the good groundwater resources in this state, when there was a $<51-75 \%$ deficit in rainfall most of the rainfed rice-growing areas were affected by mild and moderate drought (Figure 8).

\subsection{Accuracy assessment and comparison with national statistics and other studies}

The accuracy varied from $67 \%$ to $93 \%$ across the four classes (severe, moderate, mild, and no drought), with an overall accuracy of $83 \%$ (Table 4).

National rice area statistics data (Bhuvan-NRSC 2011) were compared with the rice areas derived from MODIS data for 2002. According to national statistics, the reduction in rice area was found to be about 5.48 Mha. MODIS-derived drought was estimated to be 5.28 Mha. The positive correlation has been obtained between MODIS revised rice areas and national statistics ( $r=0.92)$. The significant reduction in 2002 is attributed to reported drought conditions (INDIASTAT 2015) correlated with MODIS-derived drought areas $\left(R^{2}=84.7 \%\right)$ (Figure 9). For details see Table 5 . States with relatively small rice areas or small changes in rice area (e.g. Himachal Pradesh) should be interpreted with care due to the moderate spatial resolution of the MODIS data and the accuracy of the method as summarised in Table 4.

The changes in rice-growing areas during 2000-01 and 2002-03 were compared with the figures reported in other publications and with census data for four major ricegrowing districts in southern India (Table 6). The table shows that during 2000-01 the area under rice was 1.43 Mha but shrank to 0.92 Mha in 2002-03. By comparison, the MODIS-derived rice area was 1.41 Mha during 2000-01 and 0.88 Mha during 2002-03, whereas Biggs et al. (Biggs, Gangadhara Rao, and Bharati 2010) reported the rice area was 1.24 Mha during 2001-02 and 0.90 Mha during 2002-03. 


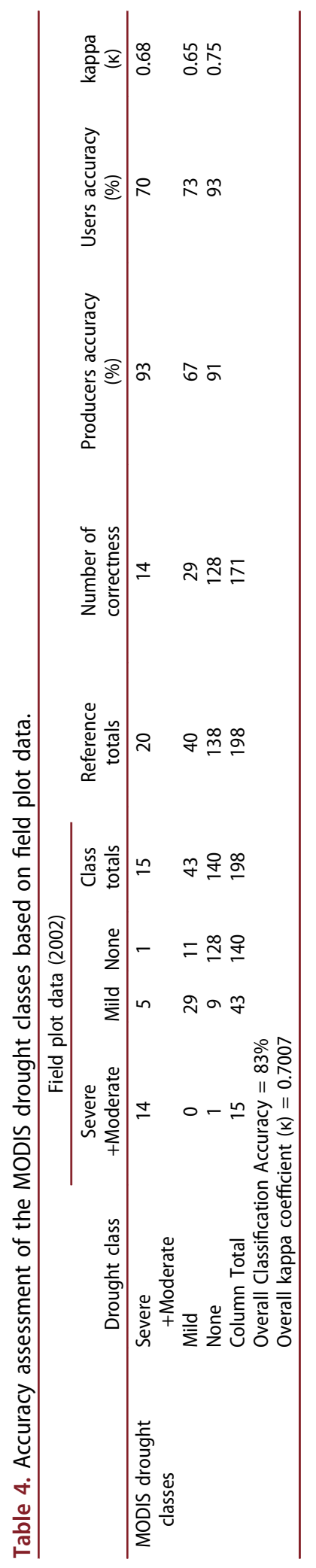




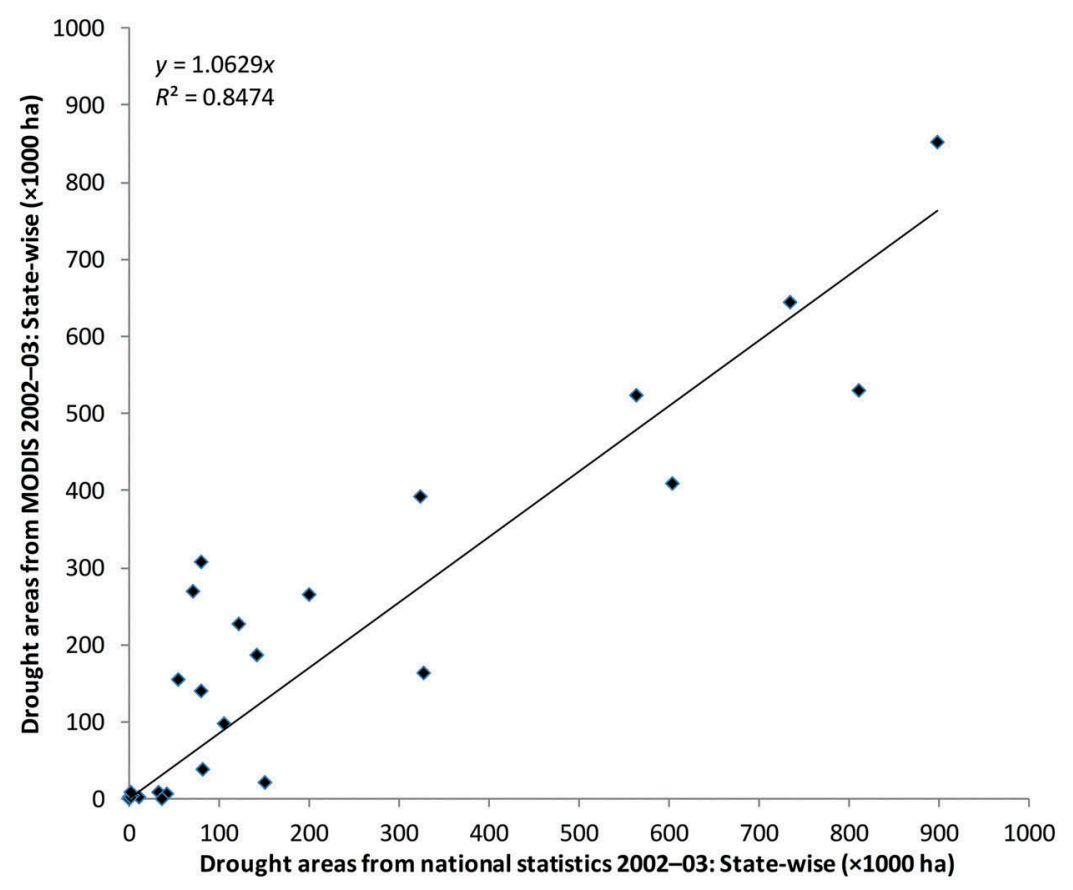

Figure 9. Comparison of MODIS vs. National agriculture statistics estimates. The drought areas derived using MODIS $500 \mathrm{~m}$ compared with state-wise agricultural statistics.

\subsection{Identification of stress-prone areas}

Given the relatively sound accuracy of the drought map for 2002-03, we applied the same classification to every kharif season in the 10-year MODIS time-series to identify drought prone rice-growing areas. We assigned a drought frequency class to each pixel (Figure 10 and Table 7). This product cannot be validated based on available data, and there are no official drought statistics to compare it against. However, it may serve as a first indication of which areas should be investigated further for drought occurrence and eventual prioritisation for interventions to mitigate drought. From this purely exploratory extension of our method, we estimated that 9,901,000 ha were affected by drought 1-2 times (mainly in crop years 2002-03 and 2009-10), while 3,684,800 ha were affected 3-5 times. A relatively small area $(1,611,000 \mathrm{ha})$ was affected five or more times.

\subsection{Discussion on assumptions, methods, and data}

We used SMTs, field plot data, MODIS time series imagery, and TRMM rainfall estimates to map drought stress in rice-growing areas of India. The method maps the estimated rice area affected by drought for the main growing season and, based on a good validation for a known drought year, it was applied to estimate the historical frequency and intensity of drought to characterise the different drought-stresses in rice growing areas. Given the accuracy of the map, the method should be explored further to map recent historical frequency and intensity of drought in rice-growing areas, but it does not predict or map 
Table 5. A comparison between the state-wise rice area ( $\times 1000 \mathrm{ha})$ calculated using the MODIS classification and the state-wise census data (NA = data not available).

\begin{tabular}{|c|c|c|c|c|}
\hline State & $\begin{array}{l}\text { MODIS rice area } \\
(2000)\end{array}$ & $\begin{array}{c}\text { MODIS rice area } \\
(2002)\end{array}$ & $\begin{array}{c}\text { Sub-national statistics } \\
(2000)\end{array}$ & $\begin{array}{c}\text { Sub-national statistics } \\
(2002)\end{array}$ \\
\hline Andhra Pradesh & 3764.4 & 3119.4 & 3956.3 & 3222.0 \\
\hline $\begin{array}{l}\text { Arunachal } \\
\text { Pradesh }\end{array}$ & 126.4 & 122.7 & 108.2 & 122.9 \\
\hline Assam & 2252.5 & 2154.3 & 2646.2 & 2541.0 \\
\hline Bihar & 3453.7 & 3184.2 & 3656.2 & 3584.9 \\
\hline Chhattisgarh & 3713.4 & 3183.2 & 3794.1 & 2983.5 \\
\hline Goa & 56.7 & 53.0 & 68.0 & 56.2 \\
\hline Gujarat & 722.1 & 566.4 & 634.6 & 580.0 \\
\hline Haryana & 1016.8 & 829.9 & 1049.0 & 906.0 \\
\hline Himachal Pradesh & 97.4 & 92.7 & $-N A-$ & - NA - \\
\hline $\begin{array}{l}\text { Jammu and } \\
\text { Kashmir }\end{array}$ & 280.1 & 258.2 & 244.1 & 92.2 \\
\hline Jharkhand & 1437.4 & 1296.8 & 1463.7 & 1383.2 \\
\hline Karnataka & 1298.5 & 1134.9 & 1481.4 & 1154.5 \\
\hline Kerala & 360.6 & 351.7 & 346.6 & 314.1 \\
\hline Madhya Pradesh & 1705.4 & 1312.0 & 1699.0 & 1374.1 \\
\hline Maharashtra & 1463.7 & 1237.3 & 1511.5 & 1389.5 \\
\hline Manipur & 192.4 & 185.6 & 212.4 & 170.0 \\
\hline Meghalaya & 109.2 & 107.2 & 106.8 & 107.7 \\
\hline Mizoram & 48.5 & 48.4 & 67.2 & 30.6 \\
\hline Nagaland & 140.6 & 140.0 & 150.5 & 150.0 \\
\hline Orissa & 4062.0 & 3537.3 & 4437.3 & 3873.6 \\
\hline Puducherry & 20.5 & 15.2 & 28.0 & 23.9 \\
\hline Punjab & 2688.1 & 2379.3 & 2611.0 & 2530.0 \\
\hline Rajasthan & 163.5 & 124.0 & 166.1 & 83.6 \\
\hline Sikkim & 0.4 & 0.4 & - NA - & 25.6 \\
\hline Tamil Nadu & 2231.6 & 1821.2 & 2113.3 & 1510.0 \\
\hline Tripura & 105.3 & 102.5 & 241.2 & 255.3 \\
\hline Uttar Pradesh & 5830.0 & 4977.5 & 5817.5 & 4919.9 \\
\hline Uttaranchal & 242.5 & 232.5 & 285.5 & 282.8 \\
\hline West Bengal & 4790.3 & 4525.5 & 5041.4 & 5081.6 \\
\hline
\end{tabular}

Table 6. District-wise area cropped to rice ( $\times 1000 \mathrm{ha})$ calculated using the MODIS classification, compared with district-wise census data and figures reported in other studies for Nagarjuna Sagar command area.

\begin{tabular}{|c|c|c|c|c|c|c|}
\hline \multirow[b]{2}{*}{ District } & \multicolumn{2}{|c|}{ District census } & \multicolumn{2}{|c|}{ Biggs, Gangadhara Rao, and Bharati 2010} & \multicolumn{2}{|c|}{ MODIS estimates } \\
\hline & $2000-2001$ & $2002-2003$ & $2000-2001$ & 2002-2003 & $2000-2001$ & $2002-2003$ \\
\hline Krishna & 394 & 246 & 354 & 225 & 374 & 222 \\
\hline Guntur & 306 & 206 & 329 & 204 & 301 & 216 \\
\hline Nalgonda & 262 & 132 & 165 & 125 & 272 & 112 \\
\hline West-godavari & 472 & 332 & 400 & 349 & 466 & 332 \\
\hline
\end{tabular}

drought occurrence on a real or near-real-time basis. While the time series can be updated every year, it is not a tool for in-season management or drought mitigation.

SMTs have been previously used to monitor crop lands for different purposes, such as mapping and classifying irrigated areas, detecting land use/land cover changes, and detecting different rice systems and rice crop intensities (Thenkabail et al. 2007; Gumma et al. 2015a, 2011a, 2014, 2016). We have demonstrated its ability to discriminate between levels of drought stress. The matching of class spectra with ideal spectra leads to quick identification and labelling of classes. 


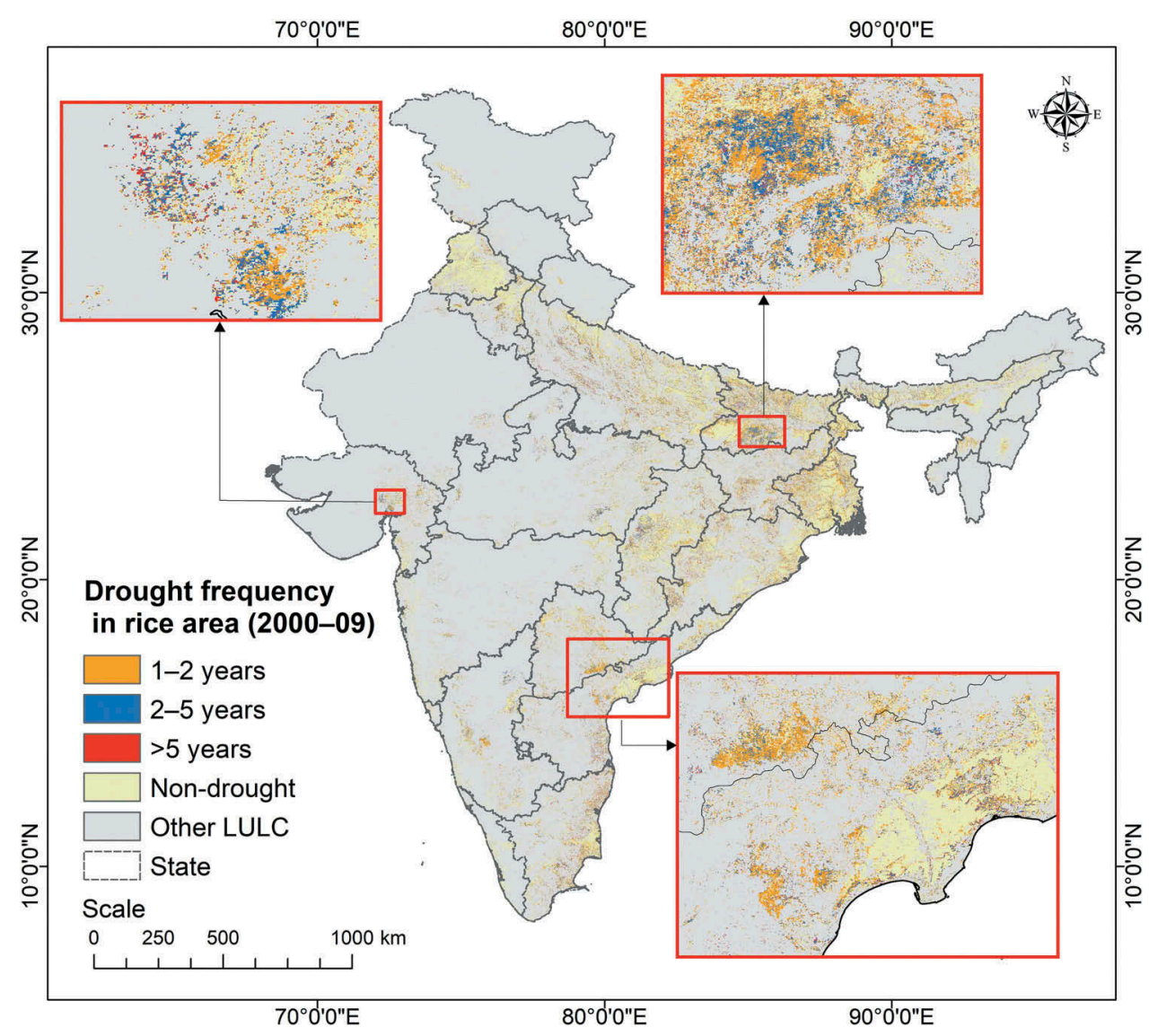

Figure 10. Identification of drought stress-prone areas (severe and moderate drought) and number of years in which stress occurred between 2000 to 2009 (LULC = land use/land cover).

SMTs require substantial field plot data to develop accurate sets of ideal spectral signatures (Gumma et al. 2016). Uncertainties and/or inaccuracies in ground data will result in class labelling errors leading to uncertainties in classes that are interpreted and mapped. The field data were collected following a protocol which has been used in past studies (Gumma et al. 2011a, 2014; Thenkabail et al. 2009) and were checked for completeness and consistency. Photographs and interviews with local partners helped ensure the quality of the field data.

Some studies have used 8-day and 16-day data to study drought using NDVI along with LSWI, NDWI, LST (Gu et al. 2007; Wan, Wang, and Li 2004). However, it is also possible to identify drought classes using monthly NDVI and LSWI, since there the monthly maximum value composite results in less cloud contamination than shorter composites. This is important in areas such as South Asia where cloud cover can be pervasive. Given the longer duration of drought stress relative to other stresses such as submergence, this lower temporal resolution was deemed appropriate to detect drought stress in rice growing regions. Eight-day composites were however used during class identification and ideal spectra generation. 
Table 7. Rice-growing areas prone to drought stress, per state, for three categories of drought frequency during the 10 years (during 2000-2009), compared with total rice areas derived from remote-sensing data for year 2000-2001.

\begin{tabular}{|c|c|c|c|c|}
\hline \multirow[b]{2}{*}{ State } & \multirow[b]{2}{*}{ MODIS rice area (×1000 ha): year 2000} & \multicolumn{3}{|c|}{ Drought frequency during 2000-2009 (×1000 ha) } \\
\hline & & $1-2$ Years & $2-5$ Years & $>5$ Years \\
\hline Andhra Pradesh & 3764 & 1177 & 384 & 155 \\
\hline Arunachal Pradesh & 126 & 13 & 8 & 6 \\
\hline Assam & 2252 & 403 & 124 & 45 \\
\hline Bihar & 3454 & 1265 & 492 & 127 \\
\hline Chhattisgarh & 3713 & 627 & 272 & 131 \\
\hline Goa & 57 & 5 & 2 & 1 \\
\hline Gujarat & 722 & 199 & 95 & 39 \\
\hline Haryana & 1017 & 197 & 88 & 33 \\
\hline Himachal Pradesh & 97 & 11 & 4 & 2 \\
\hline Jammu and Kashmir & 280 & 35 & 15 & 9 \\
\hline Jharkhand & 1437 & 491 & 175 & 103 \\
\hline Karnataka & 1299 & 328 & 144 & 62 \\
\hline Kerala & 361 & 24 & 8 & 3 \\
\hline Madhya Pradesh & 1705 & 424 & 213 & 86 \\
\hline Maharashtra & 1464 & 263 & 100 & 43 \\
\hline Manipur & 192 & 16 & 3 & 1 \\
\hline Meghalaya & 109 & 9 & 3 & 1 \\
\hline Mizoram & 48 & 0 & 0 & 0 \\
\hline Nagaland & 141 & 1 & 0 & 0 \\
\hline Orissa & 4062 & 891 & 303 & 159 \\
\hline Puducherry & 21 & 5 & 2 & 1 \\
\hline Punjab & 2688 & 240 & 83 & 32 \\
\hline Rajasthan & 164 & 53 & 26 & 12 \\
\hline Sikkim & 0 & 0 & 0 & 0 \\
\hline Tamil Nadu & 2232 & 632 & 243 & 161 \\
\hline Tripura & 105 & 11 & 2 & 1 \\
\hline Uttar Pradesh & 5830 & 1277 & 545 & 276 \\
\hline Uttaranchal & 243 & 29 & 8 & 2 \\
\hline West Bengal & 4790 & 1274 & 342 & 121 \\
\hline
\end{tabular}

While NDVI is often used to indicate drought stress, it may not be sensitive enough to detect the difference between a drought-stressed crop and a normal crop in the very early stages of the growing season when vegetation cover is low and where there is a stronger soil component in the signal. In such cases, a Soil Adjusted Vegetation Index (SAVI) may be more sensitive (Huete 1988).

Our comparison of NDVI time series across years, where the deviation in any one year against a mean is indicative of drought, implies that the seasonality is consistent from year to year. However, it is possible that a different crop, or no crop is grown in any given year. It is also possible that a farmer would delay crop establishment until there has been sufficient rainfall. Those decisions may be management responses to drought, and could lead to a difference in NDVI from the mean NDVI that could be interpreted as a crop response to drought by this method. Thus, there is a risk that our method overestimates the frequency and intensity of drought in rice growing areas. The use of $500 \mathrm{~m}$ resolution MODIS data may mitigate this somewhat, since the NDVI signal represents an average signal from many smaller fields, and such management decisions would need to be taken coherently and consistently over a large area for them to have a significant impact on the area estimated to be affected by drought. To reduce this risk further, the method could be improved by analysing the NDVI curve for any temporal shifts from year to year and their relationship with temporal shifts in accumulated 
rainfall, and by detecting any abrupt changes in the NDVI time series using methods such as BFAST (Breaks for additive seasonal and trend) (Verbesselt et al. 2010).

TRMM rainfall estimates have been previously validated with station data for the study region (Kneis, Chatterjee, and Singh 2014; Nair, Srinivasan, and Nemani 2009). Nair, Srinivasan, and Nemani (2009) conducted a study in the western part of India for seven monsoon seasons and concluded that there was some over- and under-estimation, but the timing of rain events as estimated by satellite coincided very well with station observations. Future improvements could include the use of other remotely sensed rainfall estimates with higher accuracies and higher spatial resolution than TRMM such as Climate Hazards Group Infra-Red Precipitation with Station data (CHIRPS) (CHIRP 2016).

We observed a large difference between the rainfall in the 2002 kharif season and the average kharif season rainfall for 1998-2010 and these were mapped to reveal rainfall anomalies that could be associated with drought conditions (Figure 7). The lower rainfall reported by TRMM during this time corresponded with official reports (Pandey and Bhandari 2009). No rainfall was observed (July 2002) in the severe drought ricegrowing areas. Though not much variation was observed in moderate drought areas, during the peak season (in July 2002) $196 \mathrm{~mm}$ was recorded in the drought year, compared with $281 \mathrm{~mm}$ for the 13-year July mean. Yet in July 2002, some areas in the coastal regions were affected by flood.

In addition to abiotic stresses, rice production in eastern India can be influenced by increasing labour costs, declining rice subsidy programmes, and groundwater depletion (Mohanty and Yamano 2017). However, drought remains an important factor which needs to be monitored closely because of its unpredictability and potential impact on rice production.

There have been several studies on drought within India (Murthy et al. 2009; Chandrasekar et al. 2010; Singh, Roy, and Kogan 2003; Bhuiyan, Singh, and Kogan 2006; Biggs, Gangadhara Rao, and Bharati 2010; Thenkabail, Gamage, and Smakhtin 2004). NDVI is the most commonly used index for monitoring changes in vegetation growth (Anderson et al. 2011; Steven et al. 2003). NDVI time series information is useful to create temporal profiles and identify crop signatures in rice systems (Gumma et al. 2011b, 2011a). The main advantage with $\mathrm{VCl}$ is that it is more sensitive during the wet season (November to January) and $\mathrm{TCl}$ is more sensitive in the dry season or during months with high temperature. $\mathrm{VHI}$ is an enhancement of $\mathrm{TCl}$ and $\mathrm{VHI}$ has a combination of $\mathrm{VCl}$ and $\mathrm{TCl}$ and it provides better comprehension about drought occurrence (Amalo and Hidayat 2017; Bhuiyan, Singh, and Kogan 2006). Since EVI is more sensitive to canopy variations, abiotic stresses and changes related to drought (Anderson et al. 2010), it is very useful for monitoring vegetation. Murthy et al. (Murthy et al. 2009) conducted a study in Haryana state using NDVI from NOAA AVHRR data and rainfall data for the year 2002. Results were compared against a normal year 2004. Their results correlate well with ours where a significant reduction in rice area during 2002 was observed (Table 5). Chandrasekhar et al. (Chandrasekar et al. 2010) also conducted a study for the same year in the state of Andhra Pradesh using MODIS data. That study derived LSWI characteristics and related them to a more conventional NDVI based drought assessment. Biggs et al. (Biggs, Gangadhara Rao, and Bharati 2010) studied a major irrigation system and focused on the response to water supply shocks in irrigated areas. While there is general agreement between the findings of these studies and ours, at least in cases where 
we were able to make a quantitative comparison, we believe that ours is the only one to date to look at the drought-affected rice area on a national scale.

\section{Conclusions}

Drought was mapped and characterised in the major rice growing season of 2002-03 (a major drought year) in India, using seasonal and monthly MODIS derived NDVI MVCs, with an overall accuracy of $83 \%$ and accuracy ranging from $67 \%$ to $93 \%$ across the drought classes. The characterisation was rice and season specific and may not apply to other crops or regions. The observed spatial patterns in the drought-affected rice area corresponded with reported statelevel reductions in rice area between 2000-01 and 2002-03. They also corresponded well with the against a limited amount of previously published municipal level drought area estimates. Furthermore, there was good correspondence between the drought-affected areas and differences in TRMM rainfall between the year 2002 and the 1998-2010 average providing further evidence that the approach is valid for estimating drought affected rice area across India in the kharif season. On the basis of this, the method was applied to nine years of NDVI data to map spatial and temporal patterns of drought occurrence (i.e. location and severity of drought) in the kharif season, though this was not validated.

These results suggest that our methods can be applied for large-scale mapping of drought in rice-growing areas of India. Further adaptation of the method may be required for other crops and regions and also reducing the risk of misclassification due to changes in crops or delays in crop establishment. Given the continuing availability of temporal remote sensing data, the method could be used to characterise the frequency and intensity of drought to support the targeting of technologies to boost productivity in drought-susceptible regions. However, care should be taken while working with dryland ecosystems where drought is a common phenomenon, as the thresholds and limits set for rice may not hold true for rainfed crops. Further studies need to be conducted in the drylands and arid regions to define drought in the appropriate agro-ecological context.

\section{Acknowledgments}

This research was funded by the Bill \& Melinda Gates Foundation project "Stress-Tolerant Rice for Africa and South Asia" (STRASA), CRP-GRISP and CRP-CCAFS. We thank local partners (SR Das, Orissa University of Agriculture and Technology, Odisha, Naresh Gundapeka, ESI, Hyderabad) for their support in collecting ground survey data. The authors thank Ismail Abdul, David Mackill and Devendra Gauchan for their valuable feedback on early versions of the rice classification system. The first author would like to thank Anthony Whitbread, Research Program Director, ISD, ICRISAT, for the support provided in the final editing of the paper. We thank Dr Joy Burrough-Boenisch and Dr Smitha Sitaraman, ICRISAT science editor for language editing.

\section{Disclosure statement}

No potential conflict of interest was reported by the authors. 


\section{Funding}

This research was funded by the Bill \& Melinda Gates Foundation project "Stress-Tolerant Rice for Africa and South Asia" (STRASA), CRP-GRISP and CRP-CCAFS./; CGIAR Research programs - Global Rice Science Partnership (GRiSP), Grain Legumes and Dryland Cereals (GLDC) and Climate Change, Agriculture and Food Security (CCAFS).

\section{ORCID}

Murali Krishna Gumma (D) http://orcid.org/0000-0002-3760-3935

Andrew Nelson (1) http://orcid.org/0000-0001-6202-1956

Takashi Yamano (1) http://orcid.org/0000-0001-6202-1956

\section{References}

Amalo, L. F., and R. Hidayat. 2017. "Comparison between Remote-Sensing-Based Drought Indices in East Java." Paper Presented at the IOP Conference Series: Earth and Environmental Science 54 (1). doi:10.1088/1755-1315/54/1/012009.

Anderson, J. H., K. T. Weber, B. Gokhale, and F. Chen. 2011. "Intercalibration and Evaluation of ResourceSat-1 and Landsat-5 NDVI." Canadian Journal of Remote Sensing 37 (2): 213-219. doi:10.5589/m11-032.

Anderson, L. O., Y. Malhi, L. E. O. C. Aragão, R. Ladle, E. Arai, N. Barbier, and O. Phillips. 2010. "Remote Sensing Detection of Droughts in Amazonian Forest Canopies." New Phytologist 187 (3): 733-750. doi:10.1111/j.1469-8137.2010.03355.x.

Bajgain, R., X. Xiao, P. Wagle, J. Basara, and Y. Zhou. 2015. "Sensitivity Analysis of Vegetation Indices to Drought over Two Tallgrass Prairie Sites." ISPRS Journal of Photogrammetry and Remote Sensing 108: 151-160. doi:10.1016/j.isprsjprs.2015.07.004.

Behrenfeld, M. J., J. T. Randerson, C. R. McClain, G. C. Feldman, S. O. Los, C. J. Tucker, P. G. Falkowski, et al. 2001. "Biospheric Primary Production during an ENSO Transition." Science 291 (5513): 2594-2597. doi:10.1126/science.1055071.

Benedetti, R., and P. Rossini. 1993. "On the Use of NDVI Profiles as a Tool for Agricultural Statistics: The Case Study of Wheat Yield Estimate and Forecast in Emilia Romagna." Remote Sensing of Environment 45 (3): 311-326. doi:10.1016/0034-4257(93)90113-C.

Bhat, G. S. 2006. "The Indian Drought of 2002-A Sub-Seasonal Phenomenon?" Quarterly Journal of the Royal Meteorological Society 132 (621): 2583-2602. doi:10.1256/qj.05.13.

Bhuiyan, C., R. P. Singh, and F. N. Kogan. 2006. "Monitoring Drought Dynamics in the Aravalli Region (India) Using Different Indices Based on Ground and Remote Sensing Data." International Journal of Applied Earth Observation and Geoinformation 8 (4): 289-302. doi:10.1016/j. jag.2006.03.002.

Bhuvan-NRSC. 2011. Accessed 17 October 2011. http://bhuvan.nrsc.gov.in/bhuvan/In

Biggs, T. W., P. Gangadhara Rao, and L. Bharati. 2010. "Mapping Agricultural Responses to Water Supply Shocks in Large Irrigation Systems, Southern India." Agricultural Water Management 97 (6): 924-932. doi:10.1016/j.agwat.2010.01.027.

CBIP. 2007. "Water Resources Map of India (Map No. 27)." In Central Board of Irrigation and Power. New Delhi - 110, 021. New Delhi: Maps of India.

Census. "Government of India (2001). Census of India. Accessed 02 May 2012. http://www.censu sindia.gov.in

Chandrasekar, K., M. V. R. Sesha Sai, P. S. Roy, and R. S. Dwevedi. 2010. "Land Surface Water Index (LSWI) Response to Rainfall and NDVI Using the MODIS Vegetation Index Product." International Journal of Remote Sensing 31 (15): 3987-4005. doi:10.1080/01431160802575653.

CHIRP. 2016. "Climate Hazard Group InfraRed Precipitation (CHIRP) Data Archive. Accessed 29 July 2017. http://chg.ucsb.edu/data/In 
Cihlar, J., Q. Xiao, J. Chen, J. Beaubien, K. Fung, and R. Latifovic. 1998. "Classification by Progressive Generalization: A New Automated Methodology for Remote Sensing Multichannel Data." International Journal of Remote Sensing 19 (14): 2685-2704. doi:10.1080/014311698214451.

Congalton, R. G. 1991. "A Review of Assessing the Accuracy of Classifications of Remotely Sensed Data." Remote Sensing of Environment 37 (1): 35-46. doi:10.1016/0034-4257(91)90048-B.

Daughtry, C. S. T., K. P. Gallo, S. N. Goward, S. D. Prince, and W. P. Kustas. 1992. "Spectral Estimates of Absorbed Radiation and Phytomass Production in Corn and Soybean Canopies." Remote Sensing of Environment 39 (2): 141-152. doi:10.1016/0034-4257(92)90132-4.

De Bie, C. A. J. M., M. R. Khan, V. U. Smakhtin, V. Venus, M. J. C. Weir, and E. M. A. Smaling. 2011. "Analysis of Multi-Temporal SPOT NDVI Images for Small-Scale Land-Use Mapping." International Journal of Remote Sensing 32 (21): 6673-6693. doi:10.1080/01431161.2010.512939.

DRMS. 2010. "Drought Risk Management in South Asia, SAARC Workshop, 8-9th August 2010, Kabul, Afganistan. Accessed 25 December 2012. http://saarc-sdmc.nic.in/pdf/Publications/ Drought/drought.pdf.In

Eriyagama, N., V. Smakhtin, and N. Gamage. 2009. Mapping Drought Patterns and Impacts: A Global Perspective. Colombo. Sri Lanka: International Water Management Institute. 31. (IWMI Research Report 133).

Gao, B. C. 1996. "NDWI-A Normalized Difference Water Index for Remote Sensing of Vegetation Liquid Water from Space." Remote Sensing of Environment 58 (3): 257-266. doi:10.1016/S00344257(96)00067-3.

Gaur, A., T. W. Biggs, M. K. Gumma, G. Parthasaradhi, and H. Turral. 2008. "Water Scarcity Effects on Equitable Water Distribution and Land Use in a Major Irrigation Project-Case Study in India." Journal of Irrigation and Drainage Engineering 134 (1): 26-35. doi:10.1061/(ASCE)0733-9437.

Goward, S. N., C. J. Tucker, and D. G. Dye. 1985. "North American Vegetation Patterns Observed with the NOAA-7 Advanced Very High Resolution Radiometer." Plant Ecology 64 (1): 3-14. doi:10.1007/BF00033449.

Gu, Y., F. B. Jesslyn, P. V. James, and W. Brian. 2007. "A Five Year Analysis of MODIS NDVI and NDWI for Grassland Drought Assessment over the Central Great Plains of the United States." Geophysical Research Letters 34: 6. doi:10.1029/2006GL029127.

Gumma, M. K., N. Andrew, P. S. Thenkabail, and N. S. Amrendra. 2011a. "Mapping Rice Areas of South Asia Using MODIS Multitemporal Data." Journal of Applied Remote Sensing 5: 053547. doi:10.1117/1.3619838.

Gumma, M. K., D. Gauchan, A. Nelson, S. Pandey, and A. Rala. 2011b. "Temporal Changes in Rice-Growing Area and Their Impact on Livelihood over A Decade: A Case Study of Nepal." Agriculture, Ecosystems \& Environment 142 (3-4): 382-392. doi:10.1016/j.agee.2011.06.010.

Gumma, M. K., K. Kajisa, I. A. Mohammed, A. M. Whitbread, A. Nelson, A. Rala, and K. Palanisami. 2015a. "Temporal Change in Land Use by Irrigation Source in Tamil Nadu and Management Implications." Environmental Monitoring and Assessment 187 (1): 1-17. doi:10.1007/s10661-014-4155-1.

Gumma, M. K., S. Mohanty, A. Nelson, R. Arnel, I. A. Mohammed, and S. R. Das. 2015b. "Remote Sensing Based Change Analysis of Rice Environments in Odisha, India." Journal of Environmental Management 148: 31-41. doi:10.1016/j.jenvman.2013.11.039.

Gumma, M. K., P. S. Thenkabail, A. Maunahan, S. Islam, and A. Nelson. 2014. "Mapping Seasonal Rice Cropland Extent and Area in the High Cropping Intensity Environment of Bangladesh Using MODIS 500m Data for the Year 2010." ISPRS Journal of Photogrammetry and Remote Sensing 91 (5): 98-113. doi:10.1016/j.isprsjprs.2014.02.007.

Gumma, M. K., P. S. Thenkabail, I. V. Muralikrishna, M. N. Velpuri, P. T. Gangadhararao, V. Dheeravath, C. M. Biradar, S. Acharya Nalan, and A. Gaur. 2011c. "Changes in Agricultural Cropland Areas between a Water-Surplus Year and a Water-Deficit Year Impacting Food Security, Determined Using MODIS 250 M Time-Series Data and Spectral Matching Techniques, in the Krishna River Basin (India)." International Journal of Remote Sensing 32 (12): 3495-3520. doi:10.1080/01431161003749485.

Gumma, M. K., P. S. Thenkabail, P. Teluguntla, M. N. Rao, I. A. Mohammed, and A. M. Whitbread. 2016. "Mapping Rice-Fallow Cropland Areas for Short-Season Grain Legumes Intensification in 
South Asia Using MODIS 250 M Time-Series Data." International Journal of Digital Earth 9 (10): 981-1003. doi:10.1080/17538947.2016.1168489.

Hansen, P. M., and J. K. Schjoerring. 2003. "Reflectance Measurement of Canopy Biomass and Nitrogen Status in Wheat Crops Using Normalized Difference Vegetation Indices and Partial Least Squares Regression." Remote Sensing of Environment 86 (4): 542-553. doi:10.1016/S00344257(03)00131-7.

Huete, A. R. 1988. "A Soil-Adjusted Vegetation Index (SAVI)." Remote Sensing of Environment 25 (3): 295-309. doi:10.1016/0034-4257(88)90106-X.

IMD. 2015. "Rainfall Statistics of India 2015, India Meteorological Department." Accessed 24 July 2017. http://hydro.imd.gov.in/hydrometweb/(S(djyq3in5ulrjdgurswauypnm))/landing.aspx\#

INDIASTAT. 2015. "State-Wise Net Area Irrigated by Source in India and State-Wise Irrigated Area under Crops in India." Accessed 30 May 2015. (www.indiastat.com)

Jensen, J. R. 1996. Introductory Digital Image Processing: A Remote Sensing Perspective. Upper Saddle River, New Jersey: Prentice Hall.

Justice, C. O., and P. H. Y. Hiernaux. 1986. "Monitoring the Grasslands of the Sahel Using NOAA AVHRR Data: Niger 1983." International Journal of Remote Sensing 7 (11): 1475-1497. doi:10.1080/01431168508948281.

Justice, C. O., J. R. G. Townshend, B. N. Holben, and C. J. Tucker. 1985. "Analysis of the Phenology of Global Vegetation Using Meteorological Satellite Data." International Journal of Remote Sensing 6 (8): 1271-1318. doi:10.1080/01431168508948281.

King, M. D., J. Closs, S. Spangler, and R. Greenstone. (Eds.) 2003. EOS Data Products Handbook Version 1. Greenbelt, Maryland: NASA Goddard Space Flight Center.

Kneis, D., C. Chatterjee, and R. Singh. 2014. "Evaluation of TRMM Rainfall Estimates over a Large Indian River Basin (Mahanadi)." Hydrology and Earth System Sciences 18 (7): 2493-2502. doi:10.5194/hess-18-2493-2014.

Kumar, L., K. Schmidt, S. Dury, and A. Skidmore. 2002. "Imaging Spectrometry and Vegetation Science." In Imaging Spectrometry, edited by Meer F. D., S. M. D. Jong, 111-155. Remote Sensing and Digital Image Processing 4. Dordrecht: Springer.

Kumar, S., B. M. K. Raju, C. A. Rama Rao, K. Kareemulla, and B. Venkateswarlu. 2011. "Sensitivity of Yields of Major Rainfed Crops to Climate in India." Indian Journal of Agricultural Economics 66 (3): 340.

Kummerow, C., W. Barnes, T. Kozu, J. Shiue, and J. Simpson. 1998. "The Tropical Rainfall Measuring Mission (TRMM) Sensor Package." Journal of Atmospheric and Oceanic Technology 15 (3): 809-817. doi:10.1175/1520-0426.

Manjunath, K. R., and S. Panigrahy. 2009. "Spatial Database Generation of the Rice-Cropping Pattern of India Using Satellite Remote Sensing Data." Paper presented at the International Workshop on Impact of Climate Change on Agriculture-2009 Workshop, ISPRS Ahmedabad, Ahmedabad.

Mohanty, S., and T. Yamano. "Rice Food Security in India: Emerging Challenges and Opportunities." In The Future Rice Strategy for India, edited by Mohanty, S., P.G. Chengappa, Mruthyunjaya, J. K. Ladha, S. Baruah, E. Kannan, A. V. Manjunatha, 1-13. Academic Press.

Murthy, C. S., M. V. R. Sesha Sai, K. Chandrasekar, and P. S. Roy. 2009. "Spatial and Temporal Responses of Different Crop-Growing Environments to Agricultural Drought: A Study in Haryana State, India Using NOAA AVHRR Data." International Journal of Remote Sensing 30 (11): 2897-2914. doi:10.1080/01431160802558626.

Nair, S., G. Srinivasan, and R. Nemani. 2009. "Evaluation of Multi-Satellite TRMM Derived Rainfall Estimates over a Western State of India." Journal of the Meteorological Society of Japan. Ser. II 87 (6): 927-939. doi:10.2151/jmsj.87.927.

Nguyen, T. T. H., C. A. J. M. De Bie, A. Ali, E. M. A. Smaling, and T. H. Chu. 2012. "Mapping the Irrigated Rice Cropping Patterns of the Mekong Delta, Vietnam, through Hyper-Temporal SPOT NDVI Image Analysis." International Journal of Remote Sensing 33 (2): 415-434. doi:10.1080/ 01431161.2010 .532826$.

Niranjan Kumar, K., M. Rajeevan, D. S. Pai, A. K. Srivastava, and B. Preethi. 2013. “On the Observed Variability of Monsoon Droughts over India." Weather and Climate Extremes 1: 42-50. doi:10.1016/j.wace.2013.07.006. 
Pandey, S., and H. Bhandari. 2009. "Drought, Coping Mechanisms and Poverty, the Seventh in a Series of Discussion Papers Produced by the Asia and the Pacific Division, IFAD." Accessed 01 May 2014. (http://www.ifad.org/operations/projects/regions/pi/paper/7.pdf)

Peel, M. C., G. G. S. Pegram, and T. A. McMahon. 2004. "Global Analysis of Runs of Annual Precipitation and Runoff Equal to or below the Median: Run Length." International Journal of Climatology 24 (7): 807-822. doi:10.1002/joc.1041.

Pinjarla, B., V. Chakravarthi, P. S. Roy, P. K. Joshi, and K. Chandrasekar. 2017. "Long-Term Agricultural Performance and Climate Variability for Drought Assessment: A Regional Study from Telangana and Andhra Pradesh States, India." Geomatics, Natural Hazards and Risk 8 (2): 822-840. doi:10.1080/19475705.2016.1271831.

Potter, C. S., J. T. Randerson, C. B. Field, P. A. Matson, P. M. Vitousek, H. A. Mooney, and S. A. Klooster. 1993. "Terrestrial Ecosystem Production: A Process Model Based on Global Satellite and Surface Data." Global Biogeochemical Cycles 7 (4): 811-841. doi:10.1029/93GB02725.

Running, S. W., R. Nemani, J. M. Glassy, and P. E. Thornton. 1999. "MODIS Daily Photosynthesis (PSN) and Annual Net Primary Production (NPP) Product (MOD17) Algorithm Theoretical Basis Document." In University of Montana, SCF At-Launch Algorithm ATBD Documents. (www. ntsg. umt. edu/modis/ATBD/ATBD_MOD17_v21. pdf)

Singh, R. P., S. Roy, and F. Kogan. 2003. "Vegetation and Temperature Condition Indices from NOAA AVHRR Data for Drought Monitoring over India." International Journal of Remote Sensing 24 (22): 4393-4402. doi:10.1080/0143116031000084323.

Steven, M. D., T. J. Malthus, H. Xu, and M. J. F. Baret Chopping. 2003. "Intercalibration of Vegetation Indices from Different Sensor Systems." Remote Sensing of Environment 88 (4): 412-422. doi:10.1016/j.rse.2003.08.010.

Teng, W. L. 1990. "AVHRR Monitoring of US Crops during the 1988 Drought." Photogrammetric Engineering and Remote Sensing 56: 1143-1146.

Thenkabail, P., P. GangadharaRao, T. Biggs, M. K. Gumma, and H. Turral. 2007. "Spectral Matching Techniques to Determine Historical Land-Use/Land-Cover (LULC) and Irrigated Areas Using Time-Series 0.1-Degree AVHRR Pathfinder Datasets." Photogrammetric Engineering \& Remote Sensing 73 (10): 1029-1040.

Thenkabail, P. S., C. M. Biradar, P. Noojipady, V. Dheeravath, Y. Li, M. Velpuri, M. K. Gumma, et al. 2009. "Global Irrigated Area Map (GIAM), Derived from Remote Sensing, for the End of the Last Millennium." International Journal of Remote Sensing 30 (14): 3679-3733. doi:10.1080/ 01431160802698919.

Thenkabail, P. S., M. N. Gamage, and V. U. Smakhtin. 2004. "The Use of Remotesensing Data for Drought Assessment and Monitoring in Southwest Asia." Research Report 85. Colombo, Sri Lanka: International Water Management Institute. 1-34.

TRMM. 2016. "Tropical Rainfall Measuring Mission." Accessed 10 Jan 2016. http://trmm.gsfc.nasa.gov/ Verbesselt, J., R. Hyndman, G. Newnham, and D. Culvenor. 2010. "Detecting Trend and Seasonal Changes in Satellite Image Time Series." Remote Sensing of Environment 114 (1): 106-115. doi:10.1016/j.rse.2009.08.014.

Vermote, E. F., N. Z. El Saleous, and C. O. Justice. 2002. "Atmospheric Correction of MODIS Data in the Visible to Middle Infrared: First Results." Remote Sensing of Environment 83 (1-2): 97-111. doi:10.1016/s0034-4257(02)00089-5.

Vermote, E. F., and A. Vermeulen. 1999. "MODIS Algorithm Technical Background Document, Atmospheric Correction Algorithm: Spectral Reflectances (MOD09)." NASA contract NAS5-96062.

Wan, Z., P. Wang, and X. Li. 2004. "Using MODIS Land Surface Temperature and Normalized Difference Vegetation Index Products for Monitoring Drought in the Southern Great Plains, USA." International Journal of Remote Sensing 25 (1): 61-72. doi:10.1080/0143116031000115328.

Wang, J., P. M. Rich, K. P. Price, and W. D. Kettle. 2005. "Relations between NDVI, Grassland Production, and Crop Yield in the Central Great Plains." Geocarto International 20 (3): 5-11. doi:10.1080/10106040508542350.

WorldBank. "Agriculture, Value Added (\% of GDP)." (Accessed 14 June 2016). http://data.world bank.org/indicator/NV.AGR.TOTL.ZS 
Xiao, X., S. Boles, S. Frolking, C. Li, J. Y. Babu, W. Salas, and B. Moore. 2006. "Mapping Paddy Rice Agriculture in South and Southeast Asia Using Multi-Temporal MODIS Images." Remote Sensing of Environment 100 (1): 95-113. doi:10.1016/j.rse.2005.10.004.

Zampieri, M., G. Carmona Garcia, F. Dentener, M. K. Gumma, P. Salamon, L. Seguini, and A. Toreti. 2018. "Surface Freshwater Limitation Explains Worst Rice Production Anomaly in India in 2002." Remote Sensing 10 (2): 244. doi:10.3390/rs10020244.

Zhang, C., and X. Guo. 2008. "Monitoring Northern Mixed Prairie Health Using Broadband Satellite Imagery." International Journal of Remote Sensing 29 (8): 2257-2271. doi:10.1080/ 01431160701408378. 